\title{
An Overview of Additive Manufacturing of Polymers and Associated Composites
}

\author{
Shukantu Dev Nath and Sabrina Nilufar* \\ Department of Mechanical Engineering and Energy Processes, Southern Illinois University Carbondale, \\ Carbondale, IL 62901, USA; shukantudev.nath@siu.edu \\ * Correspondence: sabrina.nilufar@siu.edu
}

Received: 8 October 2020; Accepted: 11 November 2020; Published: 17 November 2020

\begin{abstract}
Additive manufacturing is rapidly evolving and opening new possibilities for many industries. This article gives an overview of the current status of additive manufacturing with polymers and polymer composites. Various types of reinforcements in polymers and architectured cellular material printing including the auxetic metamaterials and the triply periodic minimal surface structures are discussed. Finally, applications, current challenges, and future directions are highlighted here.
\end{abstract}

Keywords: additive manufacturing; polymers; reinforcements; auxetic metamaterials; triply periodic minimal surface structures

\section{Introduction}

Additive manufacturing (AM), also commonly known as 3D printing, is a process where parts are created layer-by-layer from 3D computer model data. 3D printing technologies involve a 3D object being sliced into computer-modeled layers followed by the deposition of each layer at a time. The term AM refers to the deposition of layer upon layer. AM was first introduced commercially in 1987 with stereolithography (SLA) by 3D Systems [1]. Since then, the AM has evolved very rapidly particularly in the last decade. Many techniques have been developed including fused deposition modeling (FDM; first introduced and commercialized by Stratasys), digital light processing (DLP; by Envision TEC), solid ground curing (SGC; by Cubital and Helisys), laminated object manufacturing (LOM; by Cubital and Helisys), selective laser sintering (SLS; by DTM Corp., a sister concern of 3D Systems) [1]. The printing technologies are classified in many ways in the literature. Some of them are classified according to the methods of deposition while others are classified according to the selection of materials [2-4]. Although the journey of AM began a few decades ago, standardization of different AM techniques has been done very recently. The AM processes can be classified into seven main categories [5], namely, (1) binder jetting, (2) directed energy deposition, (3) material extrusion (FDM, 3D plotting, micro extrusion), (4) material jetting (polyjet printing), (5) powder bed fusion (SLS, selective laser melting, electron beam melting), (6) sheet lamination (LOM), and (7) vat photopolymerization (SLA, DLP, two-photon polymerization). In this review, we will highlight some of the widely used polymer AM processes. Next, we will consider the materials available for polymer AM processes. The availability of a large variety of polymers in the form of resin, filament, and powder has become a popular choice for AM processes due to low cost of manufacturing particularly for a small class of low-range machines [6-8]. Furthermore, advantages like a smaller footprint and little to no maintenance for the high-end professional system of polymer printers have made them a popular choice in recent years. However, some AM systems may suffer from system instability thus requiring frequent system calibration. Thermoplastic polymers such as ABS (acrylonitrile butadiene styrene) and its derivatives [9-11], PLA (polylactic acid) [12], 
PVA (polyvinyl alcohol) [13,14], TPU (thermoplastic polyurethane) [15,16], nylon [17] are some of the commonly used materials for 3D printing. In addition, there is a growing interest to use materials of different stiffness ranging from soft, rubber-like materials to hard plastics in AM processes which could potentially be used in shoe soles, vehicle parts, and body armor $[18,19]$.

Creating intricately shaped parts for research and commercial use can be expensive and difficult to fabricate. Before the AM revolution, thermoplastic parts were mostly made by injection molding. Nevertheless, injection molding is not profitable for small production lots. In contrast, AM has become a suitable and viable option for small production lots as it eliminates the cost of making molds [20]. Manufacturers are customizing their production using a combination of AM and injection molding [21]. Intricate parts can be fabricated with precision by AM processes nowadays. Thermo curable or photocurable acrylic and epoxy resins are among the most popular choices for printing intricate parts [22-25].

AM has found its way to myriads of applications [26]. Lightweight materials and structures manufactured by AM have potential use in marine and aerospace industries. The medical sector is utilizing the boon of AM by printing organs, tissues, blood vessel stents, etc. [27-30]. The dentistry found a way of printing accurate and custom-sized tooth, implants, and dental molds at a very reasonable cost [31]. Fabrication time also went down from weeks to several hours. Architects utilize AM processes to visualize and materialize their ideas. The cost of 3D printed buildings was reported to be cheaper than conventional construction methods. Recent NASA initiatives for MARS colonization have generated a great deal of enthusiasm for 3D printed habitats. Nevertheless, there are some serious limitations to AM. Many of these technical challenges still need to be addressed for meeting engineering demands such as customized geometry, building scalability, material heterogeneity, and structural reliability which are extensively discussed elsewhere [32-35]. This review paper aims to summarize the most recent works of AM focusing on polymers and polymer composites. Moreover, we will describe how the addition of reinforcements into the matrix materials can effectively improve the desired mechanical properties of the printed parts. Besides, we will highlight techniques for printing architectured cellular structures including the auxetics and the triply periodic minimal surface structures. Finally, we will discuss current applications, existing challenges, and future research directions of AM.

\section{Selected AM Methods for Polymer and Reinforced Polymer Composites}

\subsection{Material Extrusion}

FDM

The FDM printers are widely used and the most available printers for polymer printing. These printers utilize the filament extrusion method where the printing head melts the filament into a semi-liquid state, extrudes molten materials, and deposits single layers onto the build platform [36]. The commonly used filaments in FDM are thermoplastics such as ABS [9-11], PLA [12], PVA [13,14], TPU [15,16], ULTEM (polyetherimide) [37,38], nylon [17], ASA (acrylonitrile styrene acrylate) [39,40], and PPSF (polyphenylsulfone) [41]. The quality of printing can be varied by controlling several parameters including printing bed temperature, nozzle head temperature, nozzle size, layer thickness, printing orientation, printing speed, and raster angle [42]. Detailed studies of various processing parameters have been investigated elsewhere $[43,44]$. The study suggests proper bed temperature and controlled convective heat transfer conditions can lead to a higher bonding strength of the consecutive layers thus improve the mechanical property of the printed parts [43].

The main advantages of FDM are lower cost particularly for small footprint machines and multi-material object printing capabilities [45]. The material properties at different print locations can be optimized to exhibit different chemical and mechanical characteristics by using multiple extruders [46]. The limitations of the FDM process include the starting material to be in the filament form and the melting point of the filament cannot be very high except for some engineering polymers 
such as ULTEM and PEEK (polyetheretherketone) [38,47]. However, some micro extrusion systems eliminate the requirement to have the material in filament form altogether [48]. The possibility of the addition of different kinds of reinforcements may overcome some of these shortcomings. In addition, while printing with FDM, if the melt viscosity of the molten material is high, it may prevent extrusion and subsequently reduce printing speed. In contrast, if the melt viscosity is low, the print sections will fail due to its inability to hold unsupported sections thus creating structural instability [49]. Therefore, the range of melt viscosity of the material for FDM becomes limited. During the manufacturing of filament for FDM, the plastic is melted and extruded into a filament shape. While printing with the filament in FDM, the filament is again heated near the melting temperature. Therefore, it is critical for the filament to maintain its chemical stability and withstand physical strains regardless of temperature variations for high-quality printing [12,50].

\subsection{Vat Photopolymerization}

\subsubsection{SLA}

Stereolithography utilizes the technique of curing photopolymer with an ultraviolet (UV) laser beam. The photopolymer is kept in a resin tank while the UV laser beam moves in the $x-y$ plane and the printing base moves along the z-direction. There are two types of printing methods for SLA, namely, the top-down approach and the bottom-up approach. For the top-down printing method, a UV laser beam is pointed in a downward direction and runs along the design path on the surface of the resin. This action cures the resin and forms a layer of printing on the printing base kept at the desired depth from the resin surface. After the first layer is printed, the printing base is lowered down, and printing of the next layer starts as before. Entrapped uncured resin for some specific drawings could be a limitation of this method which can be avoided by carefully setting the printing orientation. For the bottom-up approach, a UV laser beam is directed towards an upward direction. The resin tank has an opening window at the bottom of the tank to allow the laser to pass through. The gap between the printing base and resin tank measures the layer height. UV light cures the resin under the printing base and after each layer is printed the printing base is raised according to the set layer height. Failure of base layer adhesion to the printing base limits the printing size in this process. A recent study discussed the processes and compared both "top-down" or "bottom-up" approaches [51]. According to the study, the bottom-up approach leads to more accurate and gives precise control over printing. However, detaching the printed layer from the printing bed subjects an unwanted cyclic loading on the printed part during printing. In contrast, the top-down printing approach does not apply any such loading during printing. Furthermore, very slender components become difficult to print and printing needs more support structures in the bottom-up approach compared to the top-down approach.

Acrylic and epoxy resins are typical materials used in SLA [3,52]. To make photopolymers, the photo-initiators are added to the resins $[53,54]$. Printed parts are cleaned and washed in acetone or isopropyl alcohol to dissolve the uncured resin residue found on the part surfaces. Cleaning time is carefully optimized to avoid adverse effects on the printed parts [55]. Controlling polymerization parameters including exposure time, UV intensity, speed of printing, layer thickness are very crucial to achieve proper printing with SLA [56-60]. Both top-down and bottom-up approaches provide very high resolution and accuracy [61]. However, this process is very slow compared to other methods. Slow printing speed and high resolution make SLA perfect for small precision parts.

\subsubsection{DLP}

Like SLA, DLP also cures liquid resin using UV light. The only difference being the use of a digital UV projector screen to cure the photopolymers instead of a laser beam used in SLA. The screen illuminates the pixels according to each layer of the drawing. As a result, the whole layer is printed at once, unlike SLA, resulting in a much faster build speed. 
The cured resin adheres to the printing bed one layer at a time. The screen solidifies the thin layer of resin entrapped between the printing base and resin tank base. After printing each layer, the base is uplifted to a distance allowing the liquid resins to fill up in-between space and then lowered down to a specific layer height. During the first few layers of printing, there is a suction between the printing base and the resin tank base. This may lead the layers to lose adhesion to the printing base creating printing failure. To avoid this, the uplifting speed of the printing base needs to be tuned carefully. The resolution of the prints directly depends on the pixel size of the digital screen, layer height [62], print layer exposer time [63], and bottom layer exposure time. The bottom layer exposure time is more relevant in the DLP printing approach where the bottom layer attaches to the print bed which is vital for successful printing. An additional post-curing process can be used to prevent the deformation of the thin printed parts [64]. In general, DLP has fewer moving parts and is much faster than SLA as it cures each layer all at once. A recent study demonstrated a system to print large models with a small DLP printer $[65,66]$. This system allowed to print models larger than the printing screen.

Both SLA and DLP are barely capable of printing objects below $10 \mu \mathrm{m}$. However, there is a growing demand for 3D micro/nano-AM techniques for many applications in the area of photonics, sensors, microelectromechanical systems, mechanobiology, and microfluidics [67-69]. Two-photon polymerization (2PP) is a micro AM process which is capable of printing parts as small as $100 \mathrm{~nm}$. In this method, resins consisting of monomers or oligomers are modified with photoinitiators for generating radicals after excitation. Crosslinkers are also used to ensure the insolubility in the developing solvents [70]. Resins are polymerized not by absorbing one photon, but by simultaneously absorbing two photons at longer infrared (IR) wavelength regions. In some cases, cationic polymerization is also utilized. A cationic initiator transfers a charge to the monomer units to make them reactive. These activated monomer units lead to polymer chain growth [71].

In a very recent study, researchers have 3D printed the world's smallest boat of $30 \mu \mathrm{m}$ length. It is one third smaller than the thickness of a human hair and about six times larger than a bacterium. It has remarkable detailed features with an open cockpit featuring some complicated geometry. It will allow understanding of how micro-swimmers like bacteria and sperm move through liquids which will be useful for applications in therapeutic diagnostics and drug delivery [72]. 2PP accomplishes manufacturing that is otherwise not accessible and brings new scientific possibilities for the micro/nano AM research.

\subsection{Powder Bed Fusion}

\section{SLS}

SLS is a powder bed fusion process. A high-power laser beam is targeted over a dispersed thin layer of polymer powder inside of a build chamber. As a result, the powder is melted and fused, forming a layer of solid print. The binding mechanism of SLS technology can be discussed in three main sections [73]. (A) Complete melting where materials are fully melted using the laser beam. This is suitable for metallic and ceramic materials rather than polymers. Post-processing is seldom required for this kind of operation. (B) Liquid phase assisted sintering is commonly used for materials that are difficult to sinter. This is widely used for ceramic materials mixed with a small amount of polymer additives. (C) Solid-state sintering where the powder is not fully melted in the process but rather heated between melting temperature, $\mathrm{T}_{\mathrm{m}}$ and $\mathrm{T}_{\mathrm{m}} / 2$. After the printing, post-processing is often needed [74-76].

SLS system has two powder tanks kept side by side. One is a feeder tank and the other is a printing tank. Both the chambers are kept at a temperature close to $T_{m}$ of the powder. The laser beam moves along the $x-y$ plane in a two-dimensional pattern and fuses the powder creating a printed layer. After printing of each layer, the powder bed is lowered according to layer thickness, while a new layer of fresh powder is spread over the previous layer from the feeder tank with the help of a slider or a drum. At the end of printing, the printed part is found in the printing tank and excess powder is 
removed. The excess powder material in the printing tank remains virgin and can be reused for the next printing. Polyamides (PA 11, PA 12) are the most used materials for SLS. The use of other polymers such as polyetherketoneketone (PEKK), TPU, PA 6 was commercialized with limited success [77]. The quality of the prints of SLS largely depends on the particle size, laser power, printing speed, and additional powder properties [78]. Unlike SLA, DLP, and FDM, SLS does not require structural supports for printing parts with overhanging features due to the presence of excess powder in the bed. However, post-processing is necessary for a better surface finish. The overall cost of the setup can be quite expensive because of high-power heating and high material waste [79].

\subsection{Material Jetting}

\section{Polyjet Printing}

Polyjet printing involves curing sprayed polymer with UV lights. A series of nozzles spray liquid or semi-liquid polymers to the printing bed. The sprayed polymer is continuously cured to a solid form with UV light. The series of nozzles are assembled in a gantry that moves in the $x-y$ plane. The UV light source is also attached to the gantry. After printing each layer, the printing bed is lowered along the $\mathrm{z}$-axis and makes room for the next layer of printing. Polyjet printing technology can print with any photopolymer if it is in liquid/semi-liquid form. The quality of the printing depends on the layer height, printing orientation, UV light intensity, and polymer spray rate [80-83]. The exposure time of the UV light is not variable as the UV is attached to the gantry that moves with the nozzles. Nevertheless, the exposure can be indirectly controlled by varying the rate of polymer spraying.

In polyjet printing, the printing process is very fast compared to other methods as multiple nozzles can spray polymers simultaneously. This also allows printing objects with multi-materials [84] at high-resolution $[85,86]$. Printed parts can be of different colors with a good surface finish [32] which makes this process ideal for rapid prototyping. Post-processing is not necessary for polyjet printing. The high cost of printing with a single material is a drawback of this process.

\subsection{Sheet Lamination}

\section{LOM}

LOM is a process of making 3D objects with the deposition of layers of laminated materials $[87,88]$. A sheet of plastic from a plastic roll (feed drum) is spread on the printing base. A laser moves in the $\mathrm{x}$ and $\mathrm{y}$-axis and cuts the plastic according to the drawing. First, the laser cuts a rectangular area from the sheet and then cuts the drawing pattern on the layer. Next, any area outside the pattern is cross-hatched. This cross-hatching allows for easy removal of redundant materials at the end of the printing process. After each layer of cutting, a fresh sheet of plastic from the feed drum slides on the previous layer. The residue of the printed layer is collected in a residue drum. A heated hot leveler drum rolls on the new layer of plastic to adhere to the previous layer by heat activation. After each layer is printed the printing base is lowered down according to the sheet material thickness.

LOM is one of the widely used rapid prototyping methods [89]. It does not require any structural support for printing as the residual laminated sheet acts as a support for the print. With this method, only sheet materials can be printed. The layer thickness of the sheet plays a major role in terms of surface finish and the overall quality of the printed parts [90]. In general poor surface finish and low-resolution leads to post-processing for the printed parts [91]. The width of the sheet material rolls needs to be chosen carefully to minimize material waste. Printing complex parts with this method are not feasible because of the difficulty in removing redundant materials. Figure 1 displays different AM processes related to polymer AM. 


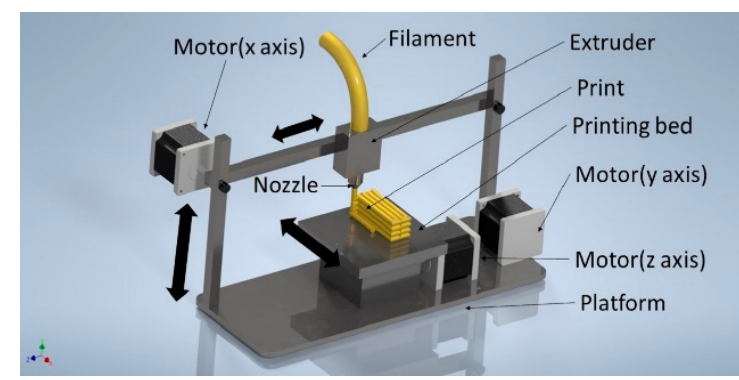

(a)

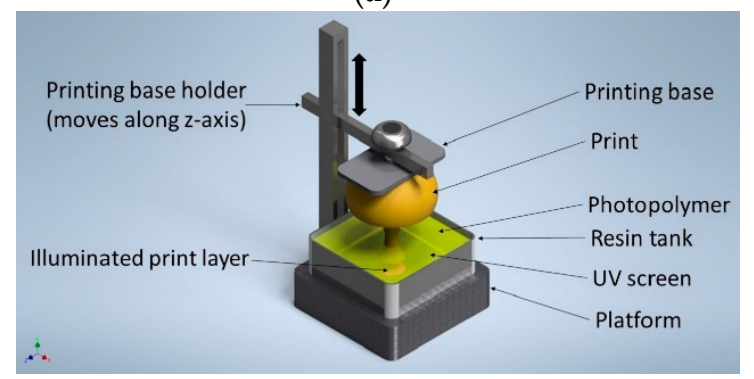

(c)

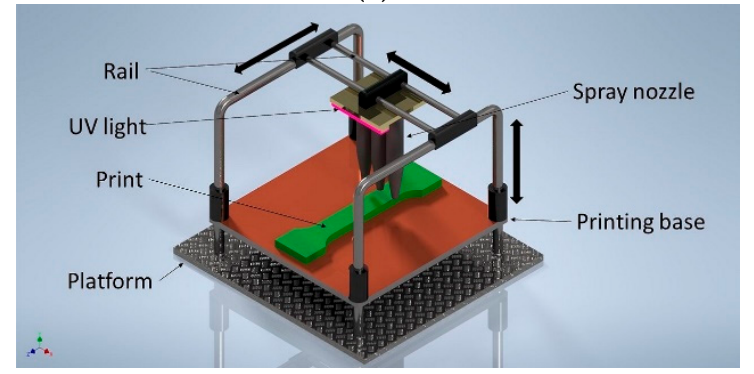

(e)

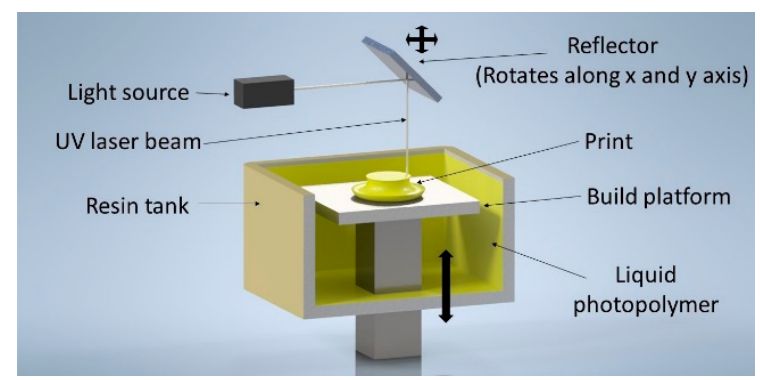

(b)

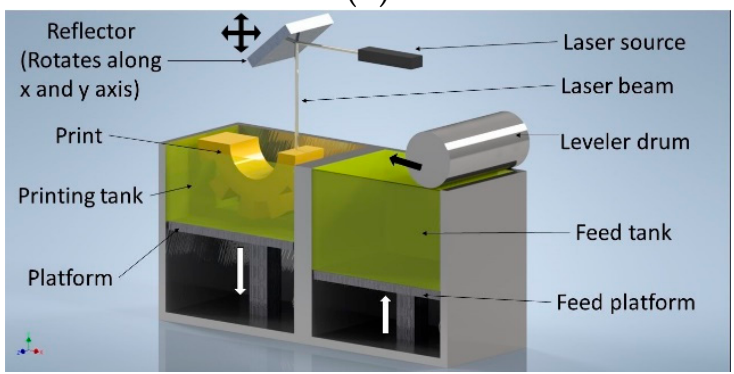

(d)

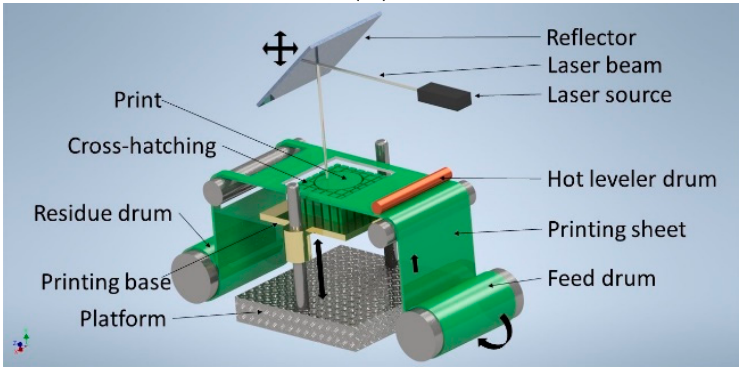

(f)

Figure 1. Selected techniques for polymer AM. (a) The Fused Deposition Modeling (FDM) printers work on the materials extrusion principle to print desired parts. (b) The stereolithography (SLA) technique uses a UV laser beam to cure liquid UV curable polymer for printing with high accuracy. (c) The digital light processing (DLP) printers print highly accurate parts using UV screens and are less time consuming than the SLA. (d) The selective laser sintering (SLS) fuses fine powder polymers with a laser beam. However, the printed parts produce rough or grainy surfaces. (e) In the polyjet printing process, fine drops of polymers are sprayed by multiple nozzles on the printing bed which are immediately cured by the UV light. It is capable of fast printing with multi-material deposition. (f) In the sheet lamination (LOM), sheets of polymers are precisely cut and added in layers to make the final product. When fast printing and large size printing capability are required, the LOM technique is preferred.

Due to thermal expansion, the thermoplastic materials expand in volume during the printing process. After printing when the printed parts reach room temperature, the differential temperature leads to shrinkage in the final product. Such shrinkage may induce residual stresses in the printed parts which results in nonuniform and unpredictable mechanical properties. This issue can partially be addressed by choosing suitable materials that have minimal shrinkable behavior. Alternatively, the nominal dimensions could be larger than the actual dimensions to accommodate such shrinkage. To minimize shrinkage, Huang et al. [92] created a library based on the shape of the print that can anticipate shrinkage of the final product and adjust the drawing accordingly. 


\section{Reinforcements in 3D Printed Parts}

Polymer 3D printed parts are weaker compared to conventionally fabricated parts. Stronger 3D printed parts are desired for load-bearing structures. Therefore, different types of reinforcements have been employed to serve this purpose. However, properly adding reinforcements remains a challenge in various printing techniques. Improving one property of the materials can negatively affect other properties. Past studies have utilized different reinforcement schemes for different processes. Reinforcements of polymer materials can be categorized into three sections, namely, (1) fiber reinforcements, (2) particle reinforcements, and (3) nanoparticle reinforcements.

\subsection{Fiber Reinforcements for 3D Printing}

Synthetic fibers such as carbon fiber (CF), glass fiber (GF), and Kevlar fiber provide excellent improvement of properties in the filaments and final parts. On the other hand, natural fibers are lightweight and cost-effective [93]. Natural fibers do not alter the biodegradability of the biodegradable polymers used in different composites. Selected fibers offer noteworthy improvement of different properties such as tensile modulus and strength, flexural properties, less distortion, shrinkage prevention, and acoustic and vibration attenuation properties. The most critical issue is the alinement of fibers in the printed parts for a given direction [94]. Among all 3D printing processes, fiber reinforcement has been extensively studied for the FDM process due to its ability to align fiber orientation. Many commercial vendors nowadays offer a wide range of fiber-reinforced filaments for FDM printing. In recent years, continuous fiber reinforcement allows introducing fibers directly into the polymer filament which eliminates the process of preparing fiber-reinforced filament for FDM printing. For example, Akhoundi et al. demonstrated that a high amount of fiber content into the PLA matrix showed improved modulus and strength of printed parts [95]. Many different continuous fiber reinforcement systems were also discussed in this study. In a separate study, a process of directly introducing fiber reinforcement into the thermoplastic filament while printing was discussed [96]. The process involves embedding a $7 \mu \mathrm{m}$ diameter $\mathrm{CF}$ filament continuously into the melted polymer filament just before the deposition of the layers. The tensile modulus of the printed part showed more than $200 \%$ improvement while the bending modulus improved around $370 \%$. The failure strain of the composite was less than that of pure PLA. Nowadays, many commercial FDM printers can print high-quality parts employing the continuous fiber reinforcement technique. Additively manufactured fiber reinforced parts have found their way in many applications such as replacement of metallic components in Formula SAE cars [97], parts in the Airbus A359XWB plane [98], reinforcement of cement mortars [99], etc.

Table 1 describes the outcome of fiber reinforcements in various polymer matrices.

Table 1. A summary of different fiber reinforcements into polymer matrices using FDM. ABS-acrylonitrile butadiene styrene; CF-carbon fiber; GF-glass fiber; PA—polyamides; PEEK—polyetheretherketone; PLA—polylactic acid; PP—polypropylene.

\begin{tabular}{llll}
\hline Matrix + Fibers & Property Evaluation & Remarks & Ref \\
\hline ABS + CF & $\begin{array}{l}\text { Composite with higher fiber length } \\
(150 \mu \mathrm{m}) \text { showed better tensile } \\
\text { properties. } 5 \text { wt. } \% \text { to } 7.5 \mathrm{wt} . \% \text { of fiber } \\
\text { content in the composite had the } \\
\text { highest tensile strength of around } 43 \\
\text { MPa. }\end{array}$ & $\begin{array}{l}\text { The mechanical properties of the } \\
\text { final parts can be achieved at an } \\
\text { optimum nozzle temperature of the } \\
\text { extruder }\left(\sim 220^{\circ} \mathrm{C}\right) .\end{array}$ & {$[100]$} \\
\hline ABS + short GF & $\begin{array}{l}\text { Improvement in tensile strength } \\
(\sim 58.60 \mathrm{MPa}) \text { at the expense of } \\
\text { flexibility and handleability. }\end{array}$ & $\begin{array}{l}\text { The addition of plasticizer and } \\
\text { compatibilizer recovered flexibility } \\
\text { and handleability to some extent. }\end{array}$ & {$[101]$} \\
\hline
\end{tabular}


Table 1. Cont.

\begin{tabular}{|c|c|c|c|}
\hline Matrix + Fibers & Property Evaluation & Remarks & Ref \\
\hline PLA + continuous CF & $\begin{array}{l}\text { Around } 200 \% \text { and } 370 \% \text { increase in } \\
\text { tensile and bending modulus, } \\
\text { respectively. }\end{array}$ & $\begin{array}{l}\text { Continuous CF reduces strain at } \\
\text { failure. } \\
\text { Annealing can increase the } \\
\text { crystalline behavior of the } \\
\text { composite. }\end{array}$ & {$[96,102]$} \\
\hline $\mathrm{PLA}+\mathrm{CF}$ & $\begin{array}{l}\text { Improvement of tensile strength by } \\
225 \% \text { ( } 28 \mathrm{MPa} \text { for pure PLA, } 80 \mathrm{MPa} \\
\text { for CF + PLA, and } 91 \mathrm{MPa} \text { for } \\
\text { modified CF + PLA) and flexural } \\
\text { strength increased by } 194 \% \text { ( } 53 \mathrm{MPa} \\
\text { for pure PLA, } 59 \mathrm{MPa} \text { for CF + PLA, } \\
\text { and } 156 \mathrm{MPa} \text { for modified CF + PLA). }\end{array}$ & $\begin{array}{l}\text { The use of a coupling agent } \\
\text { (methylene diacrylate) improves the } \\
\text { adhesion between the fiber and the } \\
\text { matrix. }\end{array}$ & [103] \\
\hline $\mathrm{PA} 12+\mathrm{CF}$ & $\begin{array}{l}277.8 \% \text { improvement of thermal } \\
\text { conductivity of the composite was } \\
\text { reported compared to pure PA } 12 .\end{array}$ & $\begin{array}{l}\text { The addition of CF increases the } \\
\text { Melt Viscosity Index thus reducing } \\
\text { the flowability leading to clogging } \\
\text { in the extruder. }\end{array}$ & [104] \\
\hline PEEK + CF & $\begin{array}{l}\text { Improvement in tensile strength from } \\
95 \mathrm{MPa} \text { to } 101 \mathrm{MPa} \text { and modulus from } \\
3.79 \mathrm{GPa} \text { to } 7.37 \mathrm{GPa} \text {. Bending and } \\
\text { compressive properties were also } \\
\text { improved. }\end{array}$ & $\begin{array}{l}\text { PEEK-GF composite showed } \\
\text { comparable mechanical properties } \\
\text { with human cortical bones. Surface } \\
\text { roughness is ideal for } \\
\text { biocompatibility, cell adhesion, } \\
\text { and spreading. }\end{array}$ & [105] \\
\hline $\mathrm{PP}+\mathrm{GF}$ & $\begin{array}{l}0^{\circ} \text { filament orientation showed the } \\
\text { highest modulus }(\sim 1.23 \mathrm{GPa}) \text { and } \\
\text { strength }(\sim 35 \mathrm{MPa}) \text {. However, } \\
\text { the addition of GF resulted in a } \\
\text { decreased melt flow rate. }\end{array}$ & $\begin{array}{l}\text { Higher printing temperatures can } \\
\text { rescue the reduced melt flow rate. } \\
\text { However, the higher printing } \\
\text { temperature may lead to distortion } \\
\text { and shrinkage of the printed parts. }\end{array}$ & [106] \\
\hline $\mathrm{PP}+$ short GF & $\begin{array}{l}\text { Tensile modulus was improved }(\sim 400 \\
\text { MPa compared to pure PP } \sim 75 \mathrm{MPa}) \\
\text { Lower flexibility and elongation at } \\
\text { break were observed. }\end{array}$ & $\begin{array}{l}\text { GF reduced the shrinkage } \\
\text { significantly. First layer adhesion } \\
\text { and distortion of parts can be } \\
\text { addressed by using GF. }\end{array}$ & [107] \\
\hline $\begin{array}{l}\text { Nylon + CF, GF, } \\
\text { Kevlar fiber }\end{array}$ & $\begin{array}{l}\text { Increased tensile strength ( } 6.3 \text { folds) } \\
\text { and flexural strength ( } 5 \text { folds). } \\
\text { However, the creep properties } \\
\text { decreased. }\end{array}$ & $\begin{array}{l}\text { Fibers were not embedded in the } \\
\text { filament but printed as layers in } \\
\text { between the Nylon layers in the } \\
\text { parts. CF reinforced Nylon } \\
\text { composite showed the highest } \\
\text { improvements in the tensile } \\
\text { strength. }\end{array}$ & {$[108,109]$} \\
\hline $\begin{array}{l}\text { Nylon + CF, GF, } \\
\text { and Kevlar fiber }\end{array}$ & $\begin{array}{l}\text { For any given infill pattern, } \\
\text { progressively higher fiber volume } \\
\text { fraction resulted in higher fatigue life. } \\
0^{\circ} \text { orientation of isotropic infill pattern } \\
\text { resulted in the highest fatigue life. }\end{array}$ & $\begin{array}{l}\text { The } 0^{\circ} \text { fiber orientation leads to high } \\
\text { stiffness. The } 45^{\circ} \text { fiber orientation } \\
\text { makes the parts ductile. The loads } \\
\text { are carried by the matrix only when } \\
\text { the fiber orientation is set at } 90^{\circ} .\end{array}$ & {$[110,111]$} \\
\hline$A B S+$ jute fiber & $\begin{array}{l}\text { The tensile modulus was increased by } \\
1 \% \text { in horizontal printing direction } \\
\text { and decreased by } 25 \% \text { in vertical } \\
\text { printing direction with the addition of } \\
5 \text { wt. } \% \text { jute fiber. Tensile strength } \\
\text { decreased around } 9 \% \text { in both } \\
\text { directions. }\end{array}$ & $\begin{array}{l}\text { Jute fibers introduced more porosity } \\
\text { in the filament. Decomposition of } \\
\text { jute is observed during extrusion } \\
\text { because of high temperature. }\end{array}$ & [112] \\
\hline $\begin{array}{l}\text { PLA + flax and } \\
\text { bamboo fibers }\end{array}$ & $\begin{array}{l}\text { High length to width ratio }(1 / \mathrm{d}) \text { of the } \\
\text { fibers leads to increased stiffness (up } \\
\text { to } 215 \% \text { ). }\end{array}$ & $\begin{array}{l}\text { The rotational speed of the filament } \\
\text { extruder influences the } l / \mathrm{d} \text { of the } \\
\text { fibers in the filament. A higher } l / \mathrm{d} \\
\text { ratio of fibers in the filament makes } \\
\text { the surface rough. }\end{array}$ & [113] \\
\hline
\end{tabular}


Table 1. Cont.

\begin{tabular}{|c|c|c|c|}
\hline Matrix + Fibers & Property Evaluation & Remarks & Ref \\
\hline PLA + jute yarn & $\begin{array}{l}\text { Improvement in tensile modulus and } \\
\text { strength were observed by } \sim 157 \% \text { and } \\
\sim 134 \% \text {, respectively. }\end{array}$ & $\begin{array}{l}\text { Impregnation of fibers into } \\
\text { filaments during extrusion resulted } \\
\text { in continuous fiber orientation. }\end{array}$ & [114] \\
\hline PLA + wood & $\begin{array}{l}\text { The density of the printed composite } \\
\text { decreased. However, the tensile } \\
\text { strength did not change significantly. }\end{array}$ & $\begin{array}{l}\text { The addition of a very high } \\
\text { percentage of wood makes the } \\
\text { surface rough. }\end{array}$ & {$[115,116]$} \\
\hline $\begin{array}{l}\mathrm{PP}+\text { hemp and } \\
\text { harakeke fibers }\end{array}$ & $\begin{array}{l}\text { Tensile modulus and strength } \\
\text { increased with the increase of hemp } \\
\text { and harakeke fibers within the } \\
\text { filaments. }\end{array}$ & $\begin{array}{l}\text { With the increasing fiber content, } \\
\text { the net shrinkage is reduced. }\end{array}$ & [117] \\
\hline PP + bamboo fibers & $\begin{array}{l}\text { Less than } 500 \mu \mathrm{m} \text { sized fibers } \\
\text { demonstrated the highest tensile } \\
\text { strength ( } 15 \mathrm{MPa} \text { for } 50 \mathrm{wt} . \% \text { fiber). }\end{array}$ & $\begin{array}{l}\text { Bamboo reinforced PP composites } \\
\text { are lightweight and water resistant. }\end{array}$ & [118] \\
\hline
\end{tabular}

In another study, CF, GF, and Kevlar fibers were introduced into nylon during printing [108]. The failure surfaces were also studied with the scanning electron microscopy (SEM) micrographs and relevant failure theories were discussed. The printed sample exhibited far superior tensile properties. Another group investigated the creep behavior of the same reinforcements in nylon [109]. Detailed fatigue analysis was conducted on the FDM printed part which shows both infill pattern and fiber volume fraction are critical to fatigue life of the fiber reinforced AM parts [110,111]. Different infill patterns (concentric, isotropic with $0^{\circ}, 45^{\circ}$, and $90^{\circ}$ ) and different fiber volume fraction have a major impact on the fatigue life of the printed specimen. As the fiber volume fraction increases the fatigue performance increases. For the same fiber volume fraction, the $0^{\circ}$ infill pattern showed the highest fatigue life.

Sometimes proper adhesion of the first layer to the printing bed becomes crucial for good quality printing when using polypropylene. The surface adhesion problem can be eliminated by adding short glass fiber [107]. Besides, short glass fiber also helps to reduce the shrinkage problem and the distortion of the final printed parts.

Natural fibers are also being utilized to improve the mechanical properties of printed parts. Depuydt and coworkers introduced flax and bamboo fiber into PLA [113]. They demonstrated that the aspect ratio of the fibers has a significant impact on the stiffness of the printed parts. They reported that a high aspect ratio of the fibers increased the stiffness of the parts by $215 \%$ compared to pure PLA while a low aspect ratio showed very minimal improvements. They extruded the fiber-reinforced PLA at different speeds. A low rotational speed allowed a high aspect ratio of the fibers in the PLA composite filament, though the surface of the filament turned out to be rough. The effect of the surface roughness needs to be studied furthermore in the future. Another example of natural fiber reinforcement involves hemp and harakeke fibers mixed into polypropylene matrix [119]. Both reinforced filament samples showed higher tensile strength and Young's modulus compared pure polypropylene matrix.

\subsection{Particle Reinforcements for $3 D$ Printing}

Particle reinforcements are becoming a popular choice for 3D printing primarily because of low cost and easy mixing with the polymer matrix. In general, particles are mixed with various polymer matrix for SLS or SLA processes and further extrusion of filaments for FDM processes. Depending on the size, filling factor (particle loading percentage), and material type, the characteristics of the resultant composites can be tailored accordingly. Some potential applications include printing soft actuators with stretchable piezo electrical composites, circuit boards with conductive particles, and multiple 3D transforming structures with ferromagnetic materials. Recent reports demonstrated the addition of metallic particles (steel and aluminum) of different filling factors into ABS filaments [120]. The smaller the particle size of metallic powder, the better the dispersion in the ABS matrix. In another study, 
the thermal conductivity of the printed composite was tuned with a higher percentage of stainless steel particles [121]. In addition to thermal properties, improvement in mechanical properties of the printed parts was achieved for up to $15 \mathrm{wt} . \%$ stainless steel particle reinforcement in ABS.

Technical ceramic particles like alumina $\left(\mathrm{Al}_{2} \mathrm{O}_{3}\right)$ were added to various polymer matrices for $3 \mathrm{D}$ printing. Introducing $\mathrm{Al}_{2} \mathrm{O}_{3}$ into low-density polyethylene (LDPE) improved the mechanical properties of the printed parts [122]. Furthermore, dimensional accuracy and higher surface finish were achieved in the reinforced composites compared to the pure polyethylene matrix. In a separate study, the introduction of $\mathrm{Al}_{2} \mathrm{O}_{3}$ particles into the Nylon- 6 matrix yielded better mechanical properties due to good dispersion into the matrix [123].

When magnetic particles are incorporated into the polymer matrix, the resultant composites can potentially act as a damper or barrier for shielding electromagnetic waves. Such composites have a great use for commercial and military applications. A recent study showed composite samples can be printed with $60-70 \%$ magnetite powder into epoxy resin and the samples showed improved compressive strength compared to neat epoxy resin [124].

The incorporation of lightweight hollow microspheres into the polymer matrix reduces the overall density of the composites [125]. Depending on the type of microspheres, the compressive properties of the composites can be tailored [126]. Dimensional stability can also be improved with the increase of microsphere content in the polymer matrix. 3D Printing with microsphere is a very recent endeavor. Singh and coworkers reported on adding fly ash cenosphere in a polymer-based filament for FDM printing $[127,128]$. The printed samples indicated an improvement in tensile properties. The same group also 3D printed composites from the cenosphere filled filaments and tested for compressive properties at various strain rates. The printed composites were lighter due to the presence of lightweight cenosphere and exhibited higher modulus at all strain rates [129].

The melt flow property of the material is an important factor for proper printing with the FDM process. When $\mathrm{Al}$ and $\mathrm{ZrB}_{2}$ microparticles were added to the ABS matrix, the melt flow index of the composite did not change significantly [130]. Due to the modification, a failure strain increase of $\sim 80 \%$ for the $\mathrm{ZrB}_{2} / \mathrm{ABS}$ and $108 \%$ for the Al/ABS composites were observed.

In Table 2, the effects of different particle reinforcements in different polymer matrices have been summarized.

Table 2. A summary of different particle reinforcements into polymer matrices. HDPE-high-density polypropylene; LDPE-low-density polypropylene; $\beta$-TCP_-beta tricalcium phosphate.

\begin{tabular}{|c|c|c|c|c|}
\hline Process & Matrix + Particle & Property Evaluation & Remarks & Ref \\
\hline DLP & $\begin{array}{l}\text { Acrylic based resin }+ \\
\text { microdiamond powder }\end{array}$ & $\begin{array}{l}\text { The heat transfer rate was improved } \\
\text { with } 30 \mathrm{wt} . \% \text { filler ( } 30 \% \text { of the time } \\
\text { required compared to the pure matrix } \\
\text { to reach the same temperature when } \\
\text { heated), decreased thermal expansion } \\
\text { coefficient, and decreased wettability. }\end{array}$ & $\begin{array}{l}\text { More suitable for high } \\
\text { temperature applications. } \\
\text { High material costs may limit } \\
\text { commercial use. }\end{array}$ & [131] \\
\hline FDM & $\mathrm{ABS}+\mathrm{TiO}_{2}$ & $\begin{array}{l}\text { Addition of } 5 \text { wt. } \% \text { filler showed } \\
\sim 13.3 \% \text { improvement in the tensile } \\
\text { strength and } \sim 11.6 \% \text { improvement in } \\
\text { the tensile modulus. }\end{array}$ & $\begin{array}{l}\text { A smoother surface finish can } \\
\text { be achieved by reducing voids } \\
\text { which leads to better and } \\
\text { consistent mechanical } \\
\text { properties. }\end{array}$ & [112] \\
\hline FDM & $\begin{array}{l}\text { ABS + stainless steel } \\
\text { particles }\end{array}$ & $\begin{array}{l}\text { The tensile strength decreased slightly } \\
\text { with the addition of stainless-steel } \\
\text { particles. Specific heat increased to } \sim 0.1 \\
\mathrm{~J} /(\mathrm{g} \mathrm{K}) \text { from } \sim 0.05 \mathrm{~J} /(\mathrm{g} \mathrm{K}) \text { (pure ABS) at } \\
\text { constant pressure and at } 200^{\circ} \mathrm{C} \text {. }\end{array}$ & $\begin{array}{l}\text { Finer particles tend to disperse } \\
\text { well. Defects and voids } \\
\text { become dominant beyond a } \\
\text { certain percentage of the } \\
\text { particles which results in the } \\
\text { decreased mechanical } \\
\text { properties. }\end{array}$ & [121] \\
\hline
\end{tabular}


Table 2. Cont.

\begin{tabular}{|c|c|c|c|c|}
\hline Process & Matrix + Particle & Property Evaluation & Remarks & Ref \\
\hline FDM & $\mathrm{ABS}+\mathrm{Al}$ and $\mathrm{ZnO}_{2}$ & $\begin{array}{l}\text { Failure strain was increased by } 80 \% \text { for } \\
\mathrm{ABS} / \mathrm{ZnO}_{2} \text { and } 108 \% \text { for } \mathrm{ABS} / \mathrm{Al} \text {. }\end{array}$ & $\begin{array}{l}\text { The addition of metal and } \\
\text { metallic powder did not } \\
\text { change the melt flow } \\
\text { properties significantly. }\end{array}$ & [130] \\
\hline FDM & $\mathrm{ABS}+\mathrm{Cu}$ and $\mathrm{Fe}$ & $\begin{array}{l}\text { The tensile modulus increased by } \\
\text { adding } 10 \text { wt. } \% \text { of } \mathrm{Cu}(\sim 930.2 \mathrm{MPa}) \text { and } \\
30 \text { wt. } \% \text { of Fe ( 978.5 MPa). However, } \\
\text { the tensile strength was decreased by } \\
\text { adding fillers. The thermal expansion } \\
\text { coefficient of the composite with } \\
50 \text { wt. } \% \mathrm{Cu} \text { was decreased by } 30 \% \text { while } \\
\text { thermal conductivity increased by } 41 \% \text {. }\end{array}$ & $\begin{array}{l}\text { Strength reduces with the } \\
\text { incorporation of fillers in the } \\
\text { composite. The addition of } \mathrm{Cu} \\
\text { in the composite resulted in } \\
\text { less distortion in the printed } \\
\text { parts. }\end{array}$ & [132] \\
\hline FDM & $\mathrm{ABS}+\mathrm{BaTiO}_{3}$ & $\begin{array}{l}\text { Improvement of relative permeability } \\
\text { was achieved by } 260 \% \text { at } 35 \text { vol. } \% \text { while } \\
\text { a } 53 \% \text { decrease in flexural strength was } \\
\text { reported at } 30 \text { vol. } \% \text {. }\end{array}$ & $\begin{array}{l}\text { Inhomogeneous particle } \\
\text { distribution may cause } \\
\text { premature mechanical failure. } \\
\text { Proper adhesion of the printed } \\
\text { parts to the bed becomes } \\
\text { challenging at higher vol. } \% \text { of } \\
\text { fillers (above } 45 \% \text { ). }\end{array}$ & [133] \\
\hline FDM & $\mathrm{LDPE}+\mathrm{Al}_{2} \mathrm{O}_{3}$ & $\begin{array}{l}\text { The compressive strength was } \\
\text { improved by } 7 \% \text {. }\end{array}$ & $\begin{array}{l}\text { Better surface finish and } \\
\text { dimensional accuracy can be } \\
\text { achieved with } \mathrm{Al}_{2} \mathrm{O}_{3} \text { addition } \\
\text { into the polyethylene matrix. }\end{array}$ & [122] \\
\hline FDM & $\begin{array}{l}\text { HDPE + fly-ash } \\
\text { cenosphere }\end{array}$ & $\begin{array}{l}\text { Density was decreased and the tensile } \\
\text { modulus was improved ( } 2.6 \text { times of } \\
\text { HDPE filament), but fracture strain was } \\
\text { decreased by about } 40 \% \text {. }\end{array}$ & $\begin{array}{l}\text { Better quality of the printed } \\
\text { parts can be achieved by } \\
\text { optimizing the layer thickness, } \\
\text { speed of the printer, print } \\
\text { temperature, and cooling } \\
\text { condition. }\end{array}$ & $\begin{array}{l}{[127,} \\
128]\end{array}$ \\
\hline FDM & Nylon + Fe & $\begin{array}{l}\text { Thermal conductivity increased by } \\
\text { increasing vol.\% and particle size of Fe. }\end{array}$ & $\begin{array}{l}\text { The metal fillers form } \\
\text { conductive particle chains in } \\
\text { the matrix. }\end{array}$ & [134] \\
\hline FDM & $\begin{array}{l}\text { PA } 12+\text { zirconia and } \\
\beta-\text { TCP }\end{array}$ & $\begin{array}{l}\text { The printed composites with } 40 \text { wt. } \% \\
\text { filler reported a tensile modulus of } 995 \\
\text { MPa compared to that of pure PA } 12 \\
(\sim 906 \mathrm{MPa}) . \text { Tensile and flexural } \\
\text { strengths decreased with increasing } \\
\text { filler content. }\end{array}$ & $\begin{array}{l}\text { Zirconia and } \beta \text {-TCP do not } \\
\text { melt with the matrix during } \\
\text { printing because of their high } \\
\text { melting point. Agglomeration } \\
\text { of the filler may cause } \\
\text { clogging. }\end{array}$ & [135] \\
\hline SLA & Epoxy resin $+\mathrm{FeO}$ & $\begin{array}{l}\text { Printed parts with a layer thickness of } \\
\text { less than } 80 \mu \mathrm{m} \text { showed consistent } \\
\text { mechanical properties. However, } \\
\text { part thickness higher than } 100 \mu \mathrm{m} \\
\text { resulted in irregular properties. }\end{array}$ & $\begin{array}{l}\text { SLA is a slow printing process. } \\
\text { Therefore, micro particle-sized } \\
\text { fillers must remain uniformly } \\
\text { dispersed in the matrix for an } \\
\text { extended period. }\end{array}$ & [136] \\
\hline SLS & PA $11+$ glass bead & $\begin{array}{l}\text { The tensile modulus was improved } \\
\text { with increasing vol. } \% \text { of glass bead } \\
\text { ( } 900 \mathrm{MPa} \text { for } 10 \%, \sim 1250 \mathrm{MPa} \text { for } 20 \% \text {, } \\
\text { and } \sim 1750 \mathrm{MPa} \text { for } 30 \%) \text {. The stiffness } \\
\text { increased, but elongation at break was } \\
\text { reduced. }\end{array}$ & $\begin{array}{l}\text { The melting depth of the } \\
\text { composite in SLS is crucial for } \\
\text { successive layer adhesion. } \\
\text { Printing settings should be } \\
\text { optimized for different vol.\% } \\
\text { of glass beads. }\end{array}$ & [137] \\
\hline
\end{tabular}

\subsection{Nanoparticle Reinforcements for 3D Printing}

The introduction of nanoparticles during AM processes is a major area of interest due to the possibility of various property enhancements including mechanical, chemical, electrical, and thermal properties of the printed parts [138-145].

Carbon nanotubes (CNT) can be used as an electrically conductive filler with photocurable resins $[146,147]$. Recently, a study showed the electrical behavior of CNT-filled 3D printable UV resin where the electrical conductivity of the printed parts was increased as a result of increased CNT content [148]. Several studies on the radar absorptivity of CNT-filled polymer composites have been conducted in the past [149-157]. In a recent study, radar absorbing composites were printed with SLA technology [158] where maximum absorption was found for 1.5\% multi-walled CNT (MWCNT) filled 
composites. CNT-filled polyimide11 showed significant improvement in the toughness of the printed samples [159]. When a crack propagates inside a nanocomposite matrix, the CNT nanofillers work as bridges between the cracks, and additional energy is required to break and pull-out the CNT resulting in higher toughness.

Improved strength and modulus were observed for vapor-grown CF (VGCF) reinforced ABS composites printed by the FDM process [160]. However, the fracture mode of the composite changed from ductile to brittle with the addition of VGCF nanoparticles. Similar results were also reported for nanoclay/ABS and nanoclay/PLA composites made by the FDM process [9,161]. A very recent study with the FDM printing process reported different morphology and mesostructures associated with the addition of nanoparticles at different stages of printing [162]. The study indicates the mechanical properties of the printed part was improved when nanoclay was mixed with the ABS filament before printing. On-site mixing of the nanoclay decreased mechanical properties possibly due to the lesser extent of exfoliation and increased surface roughness but improved dielectric property. Lastly, the nanoclay coating after the printing resulted in lower mechanical properties but the surface roughness was drastically reduced.

Anisotropy of the printed material can be expected for all AM technologies [163-166]. Anisotropy limits the engineering applications of AM manufactured parts. Poor mechanical properties were observed in both $y$ and $z$ directions [167]. To address this issue, an innovative approach was introduced where each thermoplastic layer was coated with CNT [168]. With microwave heating, the interfaces between print layers were locally welded that allowed higher diffusion of adjacent polymer layers and increased fracture strength. An increase of $275 \%$ in fracture strength was reported over the conventional FDM printed parts.

In Table 3, the effects of different nanoparticle addition into different polymer matrices have been summarized.

Table 3. A summary of different nanoparticle reinforcements into polymer matrix for 3D printing. CNT_carbon nanotubes; SWCNT_-single-walled carbon nanotubes; MWCNT_multi-walled carbon nanotubes; VGCF-vapor-grown carbon fiber; OMMT-organic montmorillonite; ATP_attapulgite; PEGDA—poly-ethylene glycol di-acrylate; Bis-GMA—bisphenol A-glycidyl methacrylate; TEGDMA—tetra-ethylene glycol di-methacrylate; GO—graphene oxide.

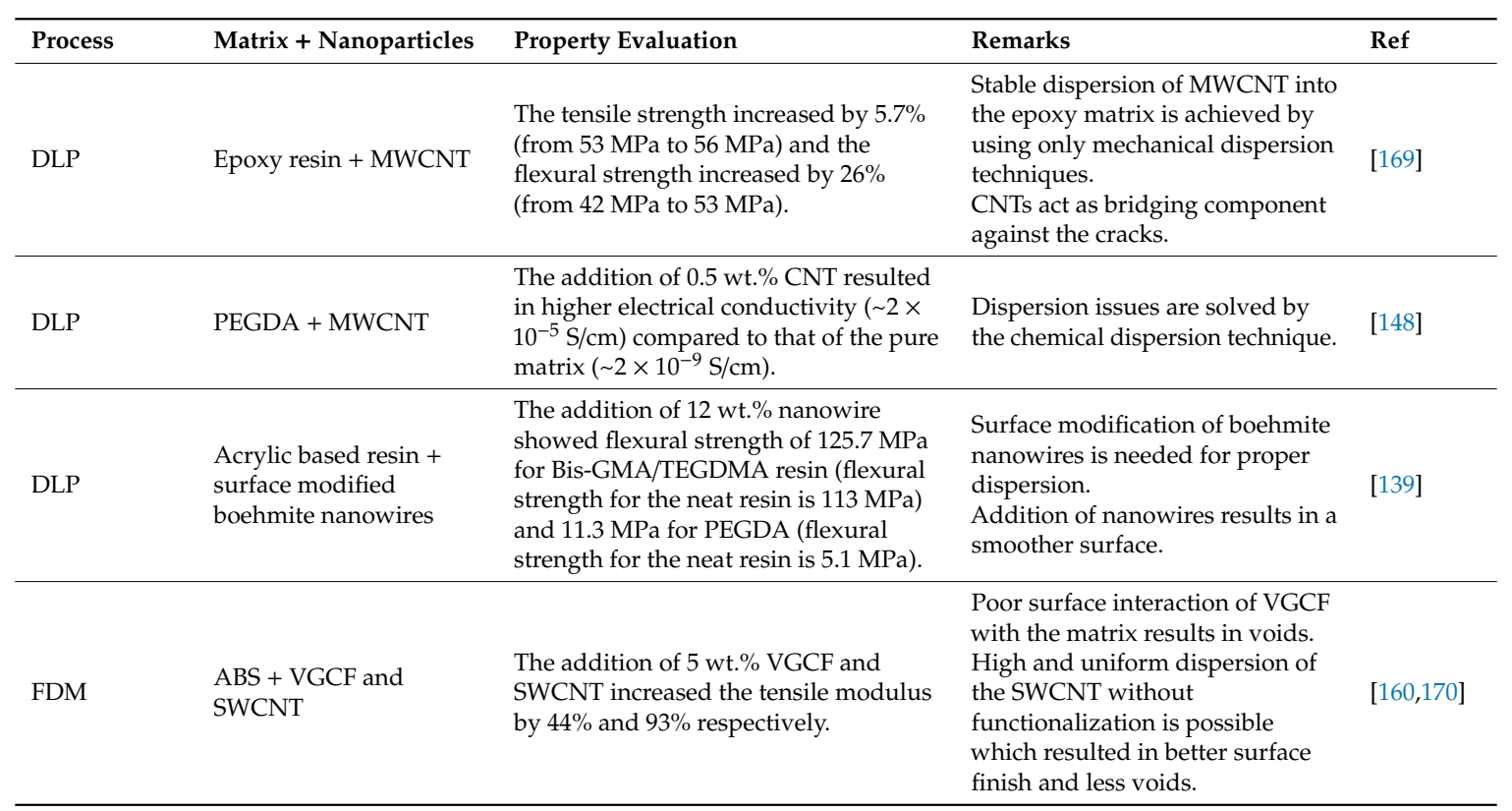


Table 3. Cont.

\begin{tabular}{|c|c|c|c|c|}
\hline Process & Matrix + Nanoparticles & Property Evaluation & Remarks & Ref \\
\hline FDM & ABS + Nanoclay & $\begin{array}{l}\text { Addition of nanoclay before printing } \\
\text { improved mechanical properties, } \\
\text { on-site of printing improved dielectric } \\
\text { properties, and coated with nanoclay } \\
\text { after printing decreased surface } \\
\text { roughness. }\end{array}$ & $\begin{array}{l}\text { The addition of nano-filler in } \\
\text { different stages of printing } \\
\text { adheres differently with the matrix } \\
\text { which changes the properties. }\end{array}$ & [162] \\
\hline FDM & PLA + graphene & $\begin{array}{l}\text { Tensile strength and modulus are } \\
\text { reported } 66.8 \mathrm{MPa} \text { and } 3752 \mathrm{MPa} \\
\text { respectively for PLA-graphene } \\
\text { composites. }\end{array}$ & $\begin{array}{l}\text { Graphene filler induces high } \\
\text { anisotropy in the printed parts. } \\
\text { Print direction must be optimized } \\
\text { for higher mechanical properties. }\end{array}$ & [171] \\
\hline FDM & PLA + MWCNT & $\begin{array}{l}\text { The fracture strength increased by } 275 \% \\
\text { compared to neat PLA printed parts. }\end{array}$ & $\begin{array}{l}\text { Enhanced interlayer adhesion of } \\
\text { the layers can be achieved with } \\
\text { microwave heating. }\end{array}$ & [168] \\
\hline FDM & PLA + Nanoclay & $\begin{array}{l}\text { Storage modulus increased by } 10 \% \text { at } \\
35^{\circ} \mathrm{C} \text { and } 50 \% \text { at } 80{ }^{\circ} \mathrm{C} \text {. }\end{array}$ & $\begin{array}{l}\text { Higher thermal stability and } \\
\text { degree of crystallinity can be } \\
\text { achieved by adding nanoclay in } \\
\text { the PLA matrix. }\end{array}$ & [161] \\
\hline SLA & $\begin{array}{l}\text { Acrylic ester resin }+ \\
\text { MWCNT }\end{array}$ & $\begin{array}{l}\text { Addition of MWCNT increases the } \\
\text { radar absorptivity. }\end{array}$ & $\begin{array}{l}\text { The addition of filler is limited to } \\
1.6 \mathrm{wt} . \% \text { due to printability issues. }\end{array}$ & [158] \\
\hline SLA & $\mathrm{PEGDA}+\mathrm{SiO}_{2}$ & $\begin{array}{l}\text { The tensile strength increased with the } \\
\text { addition of } 1 \mathrm{wt} \text {.\% silica. However, } \\
\text { the tensile modulus showed an } \\
\text { increasing trend with increasing } \\
\text { amount (up to } 5 \mathrm{wt} . \% \text { ) of silica } \\
\text { nanoparticles. }\end{array}$ & $\begin{array}{l}\text { Thermo-gravimetric analysis } \\
\text { results showed inhomogeneous } \\
\text { distribution due to the } \\
\text { agglomeration of silica } \\
\text { nanoparticle at higher loading. }\end{array}$ & [172] \\
\hline SLA & $\begin{array}{l}\text { Acrylic based resin }+ \\
\mathrm{SiO}_{2} \text {, organic } \\
\text { montmorillonite } \\
\text { (OMMT), attapulgite } \\
\text { (ATP) }\end{array}$ & $\begin{array}{l}0 \mathrm{D} \mathrm{SiO}{ }_{2} \text { did not affect curing, but } 1 \mathrm{D} \\
\mathrm{ATP} \text { and } 2 \mathrm{D} \text { OMMT structures } \\
\text { hindered the curing process. }\end{array}$ & $\begin{array}{l}\text { Geometric formation of the fillers } \\
\text { has a significant effect on the } \\
\text { curability of the printed parts by } \\
\text { vat photopolymerization. } \\
\text { Viscosity of the resin is crucial for } \\
\text { proper printability. }\end{array}$ & [174] \\
\hline SLS & PA $11+$ CNT & $\begin{array}{l}\text { Impact strength increased } \sim 54 \% \text { with } \\
\text { the addition of } 0.2 \mathrm{wt} . \% \mathrm{CNT} \text {. }\end{array}$ & $\begin{array}{l}\text { CNT causes to grow nano sized } \\
\text { microcracks under loading } \\
\text { instead of larger ones. } \\
\text { Microcracks increase the total } \\
\text { fracture surface area resulting in } \\
\text { more energy absorption. }\end{array}$ & [159] \\
\hline
\end{tabular}

The percentage of CF in a UV curable polymer should be low enough to have the proper curability of the composite and improved mechanical properties [169]. For SLA and DLP techniques, the refractive index of the printing material has a direct impact on the curability and curing time of the printing photopolymers. Added fillers in a composite may increase the mechanical, thermal, and electrical properties but the filler content and dimensional formation are crucial for the curing process. In a study, composites were filled with three silicon nanomaterials, namely, $\mathrm{SiO}_{2}, \mathrm{ATP}$, and OMMT [174]. The addition of nanofillers with more than $10 \mathrm{wt} . \%$ made the composite unsuitable for printing with SLA. Interestingly, due to the zero-dimensional formation of $\mathrm{SiO}_{2}$ nanofillers, an increase of material properties was observed with little hindrance in the curing process. In contrast, one-dimensional ATP and two-dimensional OMMT hindered the curing process, thus affecting the material properties. Other studies also showed a minimal effect in cure rate and improvement in 
mechanical and thermal properties up to $10 \mathrm{wt} . \%$ (with minimum agglomeration) for $\mathrm{SiO}_{2}$ filled composites $[9,172,175]$.

The dispersion of the nanoparticles in the base matrix is crucial for homogenous material properties. Without proper adhesion of the surfaces of the nanoparticles to the base matrix, agglomeration and sedimentation can occur. In this regard, surface treatment of the nanoparticles to promote proper adhesion to the matrix is necessary. Synthetic compounds such as silane coupling agents (SCA) are used to promote better adhesion between ceramic particles and the polymer matrix [176]. Several studies reported that SCA can be used as a coating on metallic nanoparticles to improve dispersion and surface adhesion to the polymer matrix as well. In 2007, Ukaji and coworkers studied the effect of SCA on $\mathrm{TiO}_{2}$ and found that the UV shielding ability was improved due to the treatment of particles [177]. In another study involving surface modification of $\mathrm{TiO}_{2}$ with SCAs showed better dispersion in a polyurethane matrix and improved mechanical properties [178]. Grafting an active functional group on the particle surface has been found to increase the bond strength of particle and matrix [179]. Grafting efficiency for two different SCAs on the $\mathrm{TiO}_{2}$ surfaces has been studied suggesting an improvement in particle dispersion stability [180]. The selection of SCA is a key factor for tailoring the surface characteristics of nanoparticles [181]. Improvements in mechanical and thermal properties, dispersion characteristics, effects of coating thickness for different metallic nanoparticles, and silane groups are reflected in many studies [138,182-185]. Recently, Sun and coworkers investigated the effect of SCA on zirconia nanoparticles [186]. They developed a relationship between cure depth and exposure dose of different silane group coated zirconia particles based on the polymer matrix. High shrinkage was observed in the prints but a layer thickness of $10 \mu \mathrm{m}$ was achieved by the SLA process.

\section{Selected Examples of Architectured Materials by AM Processes}

AM processes allow the fabrication of materials with multidirectional tunable properties. In this section architectured cellular materials, namely, auxetic metamaterials and triply periodic minimal surface (TPMS) structures are discussed.

\subsection{Auxetic Metamaterials}

Auxetic metamaterials are created by a series of unit cells organized in such a way that the overall material expands laterally under tension and contracts laterally when subjected to compression. This unusual deformation feature of the auxetic structures gives rise to negative Poisson's ratios. Auxetic structures have great potential for engineering applications as they are superior to conventional structures in many ways. Studies with auxetic materials reported high shear modulus [187,188], resistance to indentation [189,190], and improved fracture toughness [191,192] compared to conventional materials. 3D printing provides an ample opportunity to fabricate delicate shapes with intricate details. With 3D printing technologies, fabrication of such complex auxetic metamaterials became a reality and opened the possibility of more elaborate studies of auxetics to address future engineering demands. These auxetic metamaterials are not limited to polymers only, they can also be made with metal AM processes. Some of the practical applications of auxetic structure range from stents for angioplasty [193], shape memory alloy cellular antenna [194], footwear sole [195], and auxetic polyethylene in textile industries [196].

A study of large deformation of 3D printed auxetic shapes using SLA showed the auxetic honeycomb to exhibit a very low negative Poisson's ratio (as low as -4.0) [197]. Beyond that, the structure loses its auxeticity with further tensile deformation, and the Poisson's ratio becomes positive. Auxetic shapes offer better energy absorption capacity compared to the conventional hexagonal or rectangular shaped structures. Different structures of auxetic metamaterials exhibit different characteristics. Using FDM, with a properly tuned relative density of auxetic shapes, up to a $33 \%$ increase in energy absorption has been reported [198]. A study with four types of auxetics using material jetting technique (re-entrant chiral auxetic, re-entrant honeycomb, tetrachiral honeycomb, 
anti-tetrachiral honeycomb; Figure 2) revealed that re-entrant chiral auxetic has the highest specific energy absorption capacity under quasi-static uniaxial load [199].

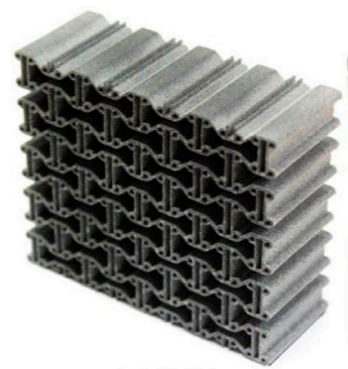

(a) RCA

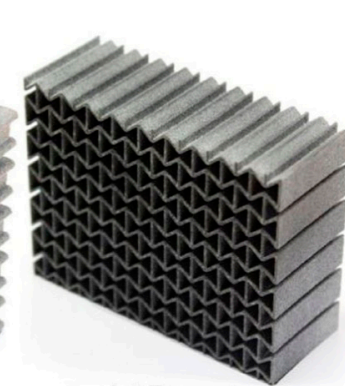

(c) Re-entrant

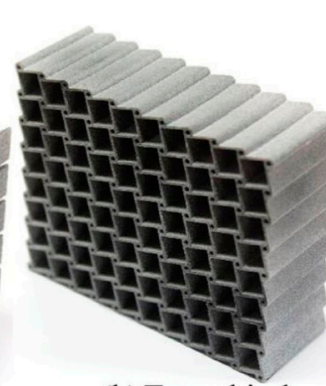

(b) Tetrachiral

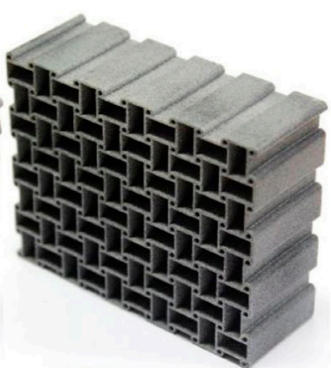

(d) Anti-tetrachiral

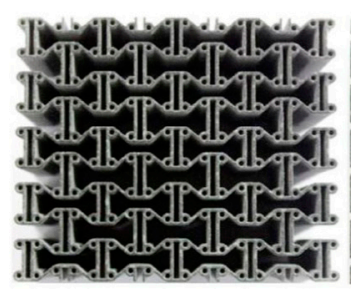

(e) RCA

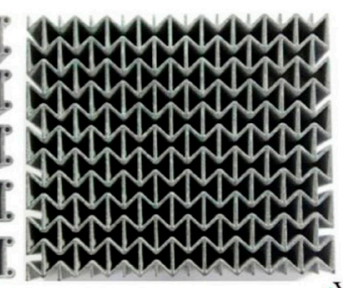

(f) Re-entrant

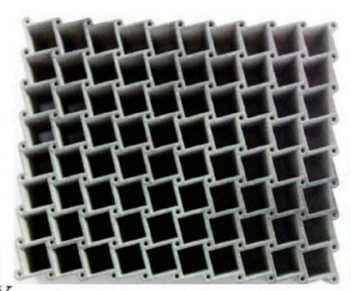

(g) Tetrachiral

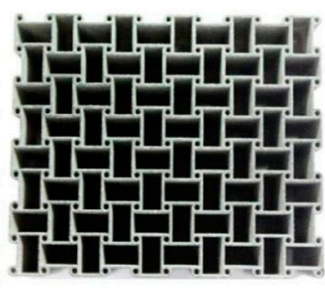

(h) Anti-tetrachiral

Figure 2. Auxetic cellular structures of different geometric shapes were printed with PA 12; (a,e) Re-entrant chiral auxetic (RCA); (c,f) Re-entrant; (b,g) Tetrachiral, (d,h) Anti-tetrachiral. Reprinted with permission from ref. [199]. Copyright 2020, Taylor and Francis.

Though auxetic structures are better for energy absorption, these are less preferable when stiffness is under consideration. Auxetic structures are less stiff which restricts its usage to structural applications. A recent study with additively manufactured auxetic structure printed with CF reinforced polymer reported an increase of stiffness of their composite metamaterial with a decrease of the re-entrant angle of the structure [200]. With a relatively small re-entrant angle, they reported higher stiffness of the structure than that of steel. Future investigations on the alignment of the fibers can potentially improve the outcome.

Auxetic metamaterials can be tuned to specific properties. Shape memory polymers (SMP) can return to its original shape when the external force is withdrawn. Many studies reported the printing of auxetic shapes with SMPs to tune the properties of metamaterials. Yuan and coworkers thermomechanically tuned auxetics printed by polyjet process with 2-stage pattern switching [201]. Zhang and others applied heat and changed the FDM printed pattern using residual thermal stress [202]. $\mathrm{Li}$ and others applied the mechanical deformation of 3D printed (vat photopolymerization) PDMS membrane with a hot press [203]. Liu and coworkers demonstrated cylindrical auxetic structures fabricated by polyjet process with a zigzag pattern having isotropic Poisson's ratio over a large range of strains [204,205]. With proper engineering, cylindrical auxetic shapes with SMP using DLP, can be used as medical stents [206].

\subsection{D Printing of Triply Periodic Minimal Surface Structures}

A triply periodic minimal surface (TPMS) is the surface of the minimal area between given boundary planes. These structures are quite fascinating, and the creation of such shapes has a rich history in mathematics. With the recent advancement in AM, TPMS generation has become an innovative way to meet engineering structural needs.

TPMS are non-self-intersecting cellular structures [207]. This family of architectured cellular structures gained special attention because of their unusual mechanical properties. TPMS has special 
and superior properties. Proper selection of TPMS structures can solve many engineering problems. Various TPMS geometric shapes have been shown to exhibit high specific stiffness [208,209]. Often TPMS geometries exhibit a large surface area which makes them ideal for their use as heat exchangers [210]. The TPMS structures printed by FDM can also provide heat insulation because of having porous structures [211]. Large deformation with compression or tension of different cellular structures helps absorbing more energy which makes them ideal for designing dampers. AM has opened a new door to study different architectured cellular geometries of TPMS. TPMS can also be beneficial for tissue engineering because of the tuning capability of pore morphology, cell interconnectivity, density, and toughness [212]. The studies of different complex shapes of TPMS structures were mostly investigated by computational simulations. Experimental studies were made possible only by the advancement in 3D printing technologies. One of the major problems of studying mechanical properties of different complex metamaterials is the discontinuity of the testing samples. Discontinuity induces stress concentration to certain areas which leads to offset or even inaccurate testing data. 3D printing processes allow TPMS structures to be continuous even for extremely complex shapes. Like auxetic metamaterials, TPMS is also not limited to polymer AM processes only. Metal AM processes also allow the generation of TPMS structures.

The gyroid structure is a special kind of TPMS known for high specific strength. NASA scientist Alan Schoen proposed a design for infinitely periodic minimal surfaces with no self-intersection back in the 1970s [213]. These structures can be found in nature. The butterfly wing scale is one of the perfect examples of gyroid structures [214,215]. Abueidda and others compared the mechanical properties of different kinds of additively manufacture TPMS structures printed using the SLS process (Figure 3) [216,217]. Among the structures, Neovius and IWP-cells showed the highest energy absorption rate. Primitive structures absorbed the least energy while the Gyroid structures were in the middle. With the increase of relative density, the structures were shown to absorb more energy [216]. For a given relative density, TPMS structures with a sheet-based TPMS network exhibits superior mechanical properties when compared to strut-based or solid TPMS structures printed by 2PP [218]. In addition, sheet-based gyroids printed by the SLA technique have been also reported to absorb more energy than the strut-based gyroids [219].

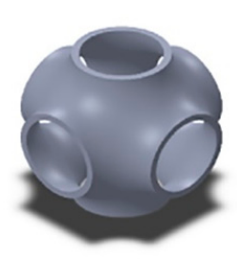

(a)

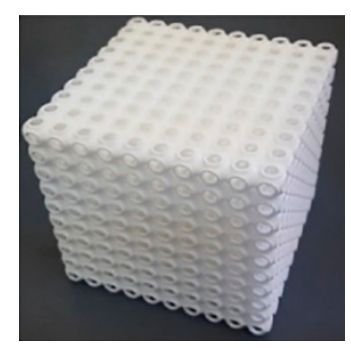

(d)

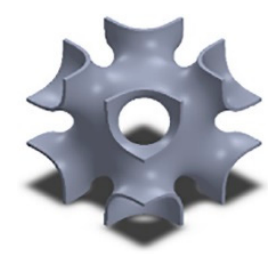

(b)

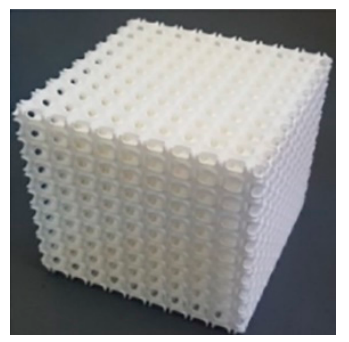

(e)

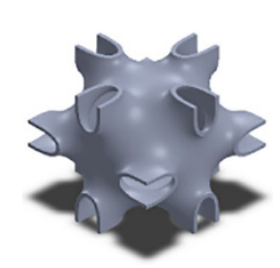

(c)

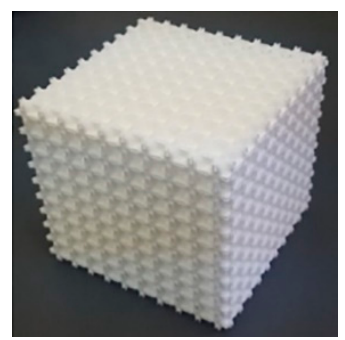

(f)

Figure 3. The first row shows computer-aided designs of gyroid structures while the second row shows corresponding printed cellular structures with a relative density of $10 \%$. (a) Primitive-Cellular Materials (CM), (b) IWP (I-graph and Wrapped package-graph)-CM, (c) Neovius-CM. 3D printed specimens: (d) Primitive-CM (relative density is $23.5 \%$ ), (e) IWP-CM (relative density is $25.6 \%$ ), (f) Neovius-CM (relative density is $23.7 \%$ ). Reprinted with permission from ref. [216]. Copyright 2017, Elsevier. 
In addition, AM also makes it possible to fabricate functionally graded materials (FGMs) in which compositions and/or microstructures gradually change along with single or multiple spatial directions for enhanced performance.

\section{Current Applications and Trends}

\subsection{Rapid Prototyping}

Advancement in polymer AM has made a significant impact on rapid prototyping. Earlier, it was time consuming, expensive, and sometimes not even feasible to make prototypes of complex shapes. Engineers had to rely on computer modeling to design commercial products with limited capabilities of prototyping. AM opened the door for many kinds of prototyping with very little time and easy accessibility. Polymer AM technologies offer the opportunity to print very accurate models with marginal expenses compared to conventional prototyping processes. Moreover, any kind of design adjustments or adaptations can be incorporated with little effort.

\subsection{Sensors and Electromechanical Systems}

With the advancements of AM technologies and the availability of a wide variety of printing materials, AM is rapidly seeping into many sectors of engineering. One of the most benefited sectors is the electromechanical systems [220,221] and various other sensor design fields [222-226]. A recent study demonstrated the fabrication of a polypropylene-based thermoplastic composite for 2D and 3D circuits by FDM printing [227]. The printed circuits showed very low variability in electrical resistance in different environmental conditions. Another study reported a highly conductive liquid sensor by PLA-CNT nanocomposite using the FDM printing process [228]. Many engineering applications demand a flexible and complex circuit design. AM can tackle the printing of such flexible circuits with great ease [229].

The piezoresistive effect is a change in electrical resistivity with applied strain. FDM printed polymer matrix and CNT nanocomposite can be used to make strain sensors with tunable piezoresistive properties [223-225]. 3D printing of a multiaxial force sensor can eliminate the sequential steps of individual sensor fabrication followed by assembly steps [226]. With 3D printing, sensors can be printed directly without any sub-steps. A study demonstrated the ability to printing sensors and embedding it into a 3D printed part at the same time [222]. 3D printed temperature sensors showed excellent accuracy, various usability, and consistency [230,231].

\subsection{Aerospace Industry}

Metal AM has already made its way to the aerospace industry [232]. Different heavy-duty and functional engine parts are being manufactured by metal AM processes [233]. The aerospace industry started to embrace the convenience of design flexibility and reliability of metal parts made by AM. Likewise, polymers or polymer composites are being used in relatively low temperature areas such as fan duct, engine access panel, compressor vanes, fan bypass stator, and acoustic liner of engines [234].

PEKK and CF composite materials are high heat resistant, chemically inert, and mechanically strong. AM parts with the PEKK composite have potential use in the aerospace industry [235]. 3D printed ULTEM composites (family of PEI) are also good options for high-performance applications [236]. Polymer AM in unmanned aerial vehicles (UAV) is gaining popularity because of lightweight printed parts, ease of fabrication of aerodynamic shapes, and options for flexible design changes and/ or repair even in remote locations [237].

\subsection{Automotive Industry}

AM of polymer and polymer composites went from prototyping to production stage for automobile components such as car bumpers, windbreakers, interior/exterior trims using SLS AM processes. 
The supply of many spare parts for the automotive industry will be readily available as the AM technology matures [238].

\subsection{Academic Institutions}

One of the most benefited sectors of AM processes is education. Polymer 3D printing is cheap and easily available. It is being used to demonstrate ideas and model designs for K-12 outreach programs [239]. $3 \mathrm{D}$ printing has major implications in special education as well [240,241]. The importance and applications of 3D printing in human anatomy education are also vital [242,243]. 3D printing of molecular models can help the students visualize the structure more effectively [244,245].

\subsection{Biomedical Applications}

Polymers are widely used biomaterials for 3D printing. Both biodegradable and non-degradable polymers are available, but biodegradable polymers are widely used. Recently, many synthetic polymers have been developed with a tunable degradation rate. Hydrogels are a type of polymer that is used in a variety of applications including cell encapsulation, drug delivery systems, and scaffolds. Various 3D printing methods (FDM, SLA, DLP, etc.) have been adopted in studies to create scaffolds for specific tissues [246,247].

Drug development is benefited by AM processes. Drug dosage can also be tuned according to the prescriptions. Pharmaceutical companies are working on drugs which will be 3D printed with specific characteristics matching the individual patient dosage needs. FDM printing has found its way into drug research and development where thermoplastic polymers such as PVA have been utilized as drug carriers [248]. Researchers also demonstrated the capability of FDM in printing PVA filaments exhibiting an extended drug release of prednisolone for up to $24 \mathrm{~h}$ following oral administration [249]. However, a significant limitation for the use of FDM is the elevated temperature required for its operation, which may degrade a significant number of pharmaceutical excipients and active drugs [250]. Other water soluble polymers such as PVP (polyvinylpyrrolidone), and PAA (polyacrylic acid) are also used as excipients in drugs fabricated by AM [251].

Stents are made by the FDM technique using Silbione RTV 4439 A\&B from Elkem Silicones, Oslo, Norway and polycaprolactone (PCL) is being used to prevent blocking or collapsing of blood vessels $[252,253]$. As the AM technology matures, we can fabricate and replace human organs using patients' own cells that would minimize tissue rejection. Researchers have been able to fabricate prosthetics using AM processes [254-256]. AM processes enable to fabricate prosthetics to match the patient's body structure. The quality and functions can be further adjusted.

\subsection{AM Technologies in Dentistry}

AM technologies have an obvious application in the field of dentistry. Many 3D printing companies specifically make 3D printers for prosthodontics applications. Polymers are mostly used to make the casting patterns for dentures. A complete denture or a part can be cast with metal from the printed patterns, which makes the process inexpensive, fast, and extremely precise. Ongoing research focuses on further material development to print dentures directly with 3D printing. Recently, the fabrication of artificial functional teeth with hard polymers and ceramics has become quite common [257].

Metal bracing was a popular option for straightening misaligned teeth. Discomfort, soft tissue injury, stuck food behind the braces, and overall appearances were among some of the issues with metal braces. Recently, 3D printed dental aligners utilize a series of clear and removable frames to gradually align the misplaced teeth [258]. These frames can be easily customizable for each patient according to their teeth size and shape. 3D printed dental models are being used for educational purposes as well.

Vat photopolymerization (SLA) technology is utilized in implant dentistry, as well as their applications in the field such as manufacturing surgical guides, custom trays, working implant casts, and provisional restorations [259]. 


\subsection{AM in Vibration and Noise Control}

Phononic Crystals are metamaterials with a periodic combination of scatterers in a matrix [260]. They exhibit the property of blocking frequencies of acoustic and elastic waves within a certain range, called a bandgap. For a given phononic crystal bandgap width, the frequency and isotropy depend on the topology, geometric structure, and properties of the materials of a unit cell [261]. AM has a huge advantage for the fabrication of phononic crystals and acoustic metamaterials. Resonators in the acoustic metamaterials can be achieved with different complex shapes, which are sometimes challenging to make with conventional methods. Conventionally fabricated phononic crystals and acoustic metamaterials lack tunable bandgap range which can be a big limitation [262]. AM leads the way to overcome this. 3D printing of the scatterers in the phononic crystals has become more common than before due to the advancement of AM technologies [263-269]. With the help of SLS, auxetic structures made of PA 12, was the first demonstration of a single-phase 3D periodic structure with wide tunable bandgap [270]. AM technologies are also utilized for improving the performance of acoustic metamaterials [271]. 3D printed samples of acoustic metamaterials were made by FDM, DLP, and SLA processes and subsequently compared the results with numerical modeling [271]. It was concluded that the divergence between numerical modeling and experimental results arises due to the difference in surface roughness of the printed samples.

\subsection{Others}

Manufacturing of eyewear frames is expensive as it goes through several steps such as modeling, cutting, heating, and reshaping, then polishing and assembling. AM can reduce some of the steps and make the design adjustments easier for the manufacturer. Among many, Fritz Frames Company is making some excellent AM printed glass frames. An interesting study indicated the security features offered by AM technologies by printing security labels with programable or customized geometry [272]. Under Armour and Adidas commercialized shoes with 3D printed soles. Carbon 3D introduced advanced helmet technology with 3D printed latticing support. These helmets can be customized according to the size and shape of the player's head. A long ride on a bicycle can be very uncomfortable with an improper saddle. Extremely lightweight and comfortable saddles are made by using various AM technologies. AM processes are also utilized in making jewelry. Very recently, with the outbreak of the COVID-19 pandemic, AM technologies have been in use for 3D printing of face shields and masks to meet the market demand.

\section{Challenges and Future Directions}

AM processes allow design flexibility, customization, and rapid prototyping at an unprecedented level. The current application bubble is expanding at such a rapid rate that very soon it will affect all walks of life. From rapid prototyping to large scale manufacturing, certain challenges need to be addressed. First and foremost is the slow production speed of current AM systems. Therefore, there is a tremendous push for research and development of high-speed AM processes. Before the industry can adopt AM for large scale manufacturing, AM systems should be capable of producing parts in a matter of seconds to minutes rather than hours and days. The next big challenge is the availability of a narrow range of materials suitable for AM processes and the high cost of materials. Although the list of available materials is growing, it is not expanding fast enough and more importantly, there is no shared database of available printing materials and their properties. Along the line, materials used for AM processes are rather proprietary. This gives rise to another issue, i.e., heterogeneity in material properties, lot-to-lot variation, printed part variability, and quality control issues. Although AM processes are championed for less material waste compared to conventional processes, there is plenty of room for improvement in reducing materials waste. Furthermore, there is a vacuum of established industry-wide standards including guidance for green manufacturing. Moreover, design software availability, feeding the files for printing, and manual post-processing slows down the workflows. Finally, there is a size limitation. 
At one end of the spectrum, the manufacturing of large products becomes a bottleneck. On the other end of the spectrum, the printing resolution needs improvement. The bottom line, there is still a lot of room for future improvement to reap the full benefits of AM processes.

As for future work, we need to work towards reducing the gap between our current capabilities and expectation. Some of the major future directions are discussed here:

- The cost of polymer printed parts compared to conventional processes such as injection molding is higher. The ability to produce a large lot in a short period is the key to success. This will allow the transition from rapid prototyping to large-scale manufacturing in many industries. However, the use of AM processes does not need to compete with conventional polymer manufacturing processes rather the advantages of AM processes should be better utilized for finding solutions to unique problems.

- Low material cost, less waste, reuse of materials, low energy consumption, less manpower-all these factors can be combined to make the manufacturing greener.

- At present, the strength of printed parts can become a serious issue. This can be partially addressed by using reinforcements but still requires further research.

- The surface finish of printed parts is not satisfactory for some of the AM processes. The finish of prints with reinforcements is even worse. A better surface finish could eliminate the requirement for time-consuming post-treatment and save time and money.

- As most industries do not have a comprehensive R\&D division, they tend to rely on vendors for any AM related processes. Therefore, the need for skilled workforce development in AM can be envisioned.

- Despite a vast application of 3D printing in different sectors, we are still limited to a very little variety of materials. The printing materials must be in filament, liquid, or fine powder form and cannot be reused once printed. This is a huge limitation for large-scale production. Synthesis of new materials with desired properties, new reinforcement capabilities, and reusable raw materials need to be explored further.

\section{Conclusions}

Polymers are base materials for majority of AM processes. Technological improvement and investigations in polymers as $3 \mathrm{D}$ printing materials is a fast-evolving field. Our goal is to put together a collection of very recent publications exploring various polymer AM processes related to reinforcements, different unusual cellular shapes, and highlight current accomplishments. AM has the potential to have a long-lasting impact in our day to day life but still have a long way to go to address the current challenges and drive towards future goals.

Author Contributions: S.N. conceived the manuscript topic, acquired funding, reviewed, edited, and supervised the manuscript. S.D.N. wrote the original draft. Both authors have read and agreed to the published version of the manuscript. All authors have read and agreed to the published version of the manuscript.

Funding: S.N. acknowledges SIUC new faculty startup fund and 2020 MTC Seed grant.

Conflicts of Interest: The authors declare no conflict of interest.

\section{References}

1. Wohlers, T.; Gornet, T. History of additive manufacturing. Wohlers Rep. 2014, 24, 118.

2. Stavropoulos, P.; Foteinopoulos, P. Modelling of additive manufacturing processes: A review and classification. Manuf. Rev. 2018, 5, 2. [CrossRef]

3. Taormina, G.; Sciancalepore, C.; Messori, M.; Bondioli, F. 3D printing processes for photocurable polymeric materials: Technologies, materials, and future trends. J. Appl. Biomater. Funct. Mater. 2018, 16, 151-160. [CrossRef] 
4. Calignano, F.; Manfredi, D.; Ambrosio, E.P.; Biamino, S.; Lombardi, M.; Atzeni, E.; Salmi, A.; Minetola, P.; Iuliano, L.; Fino, P. Overview on additive manufacturing technologies. Proc. IEEE 2017, 105, 593-612. [CrossRef]

5. ISO/ASTM52900-15. Standard Terminology for Additive Manufacturing-General Principles-Terminology; ASTM International: West Conshohocken, PA, USA, 2015. [CrossRef]

6. Horn, T.J.; Harrysson, O.L.A. Overview of Current Additive Manufacturing Technologies and Selected Applications. Sci. Prog. 2012, 95, 255-282. [CrossRef]

7. Waheed, S.; Cabot, J.M.; Smejkal, P.; Farajikhah, S.; Sayyar, S.; Innis, P.C.; Beirne, S.; Barnsley, G.; Lewis, T.W.; Breadmore, M.C. Three-Dimensional Printing of Abrasive, Hard, and Thermally Conductive Synthetic Microdiamond-Polymer Composite Using Low-Cost Fused Deposition Modeling Printer. ACS Appl. Mater. Interfaces 2019, 11, 4353-4363. [CrossRef]

8. Postiglione, G.; Natale, G.; Griffini, G.; Levi, M.; Turri, S. Conductive 3D microstructures by direct 3D printing of polymer/carbon nanotube nanocomposites via liquid deposition modeling. Compos. Part A Appl. Sci. Manuf. 2015, 76, 110-114. [CrossRef]

9. Weng, Z.; Wang, J.; Senthil, T.; Wu, L. Mechanical and thermal properties of ABS/montmorillonite nanocomposites for fused deposition modeling 3D printing. Mater. Des. 2016, 102, 276-283. [CrossRef]

10. Nuñez, P.; Rivas, A.; García-Plaza, E.; Beamud, E.; Sanz-Lobera, A. Dimensional and surface texture characterization in fused deposition modelling (FDM) with ABS plus. Procedia Eng. 2015, 132, 856-863. [CrossRef]

11. Samykano, M.; Selvamani, S.; Kadirgama, K.; Ngui, W.; Kanagaraj, G.; Sudhakar, K. Mechanical property of FDM printed ABS: Influence of printing parameters. Int. J. Adv. Manuf. Technol. 2019, 102, 2779-2796. [CrossRef]

12. Cuiffo, M.A.; Snyder, J.; Elliott, A.M.; Romero, N.; Kannan, S.; Halada, G.P. Impact of the fused deposition (FDM) printing process on polylactic acid (PLA) chemistry and structure. Appl. Sci. 2017, 7, 579. [CrossRef]

13. Ni, F.; Wang, G.; Zhao, H. Fabrication of water-soluble poly (vinyl alcohol)-based composites with improved thermal behavior for potential three-dimensional printing application. J. Appl. Polym. Sci. 2017, 134. [CrossRef]

14. Goyanes, A.; Kobayashi, M.; Martínez-Pacheco, R.; Gaisford, S.; Basit, A.W. Fused-filament 3D printing of drug products: Microstructure analysis and drug release characteristics of PVA-based caplets. Int. J. Pharm. 2016, 514, 290-295. [CrossRef]

15. Xiao, J.; Gao, Y. The manufacture of 3D printing of medical grade TPU. Prog. Addit. Manuf. 2017, 2, 117-123. [CrossRef]

16. Han, Y.; Kim, J. A study on the mechanical properties of knit fabric using 3D printing-Focused on PLA, TPU Filament. J. Fash. Bus. 2018, 22, 93-105.

17. Knoop, F.; Schoeppner, V.; Knoop, F.; Schoeppner, V. Mechanical and thermal properties of FDM parts manufactured with polyamide 12. In Proceedings of the 26th Annual International Solid Freeform Fabrication Symposium-An Additive Manufacturing Conference, Austin, TX, USA, 10-12 August 2015; pp. 10-12.

18. Dong, G.; Tessier, D.; Zhao, Y.F. Design of Shoe Soles Using Lattice Structures Fabricated by Additive Manufacturing. In Proceedings of the Design Society: 22nd International Conference on Engineering Design, Delft, The Netherlands, 5-8 August 2019; pp. 719-728. [CrossRef]

19. Benzait, Z.; Trabzon, L. A review of recent research on materials used in polymer-matrix composites for body armor application. J. Compos. Mater. 2018, 52, 3241-3263. [CrossRef]

20. Franchetti, M.; Kress, C. An economic analysis comparing the cost feasibility of replacing injection molding processes with emerging additive manufacturing techniques. Int. J. Adv. Manuf. Technol. 2017, 88, 2573-2579. [CrossRef]

21. Gaub, H. Customization of mass-produced parts by combining injection molding and additive manufacturing with Industry 4.0 technologies. Reinf. Plast. 2016, 60, 401-404. [CrossRef]

22. Andrzejewska, E.; Andrzejewski, M. Polymerization kinetics of photocurable acrylic resins. J. Polym. Sci. Part A Polym. Chem. 1998, 36, 665-673. [CrossRef]

23. Voet, V.S.; Strating, T.; Schnelting, G.H.; Dijkstra, P.; Tietema, M.; Xu, J.; Woortman, A.J.; Loos, K.; Jager, J.; Folkersma, R. Biobased acrylate photocurable resin formulation for stereolithography 3D printing. ACS Omega 2018, 3, 1403-1408. [CrossRef] 
24. Zhao, T.; Li, X.; Yu, R.; Zhang, Y.; Yang, X.; Zhao, X.; Wang, L.; Huang, W. Silicone-epoxy-based hybrid photopolymers for 3D printing. Macromol. Chem. Phys. 2018, 219, 1700530. [CrossRef]

25. Vieira, L.; Paggi, R.; Salmoria, G. Thermal and dynamic-mechanical behavior of fullcure 3d printing resin postcured by different methods. In Innovative Developments in Virtual and Physical Prototyping: Proceedings of the 5th International Conference on Advanced Research in Virtual and Rapid Prototyping, Leiria, Portugal, 28 September-1 October 2011; Taylor \& Francis Froup: Lonmdon, UK, 2011; p. 385.

26. Berman, B. 3-D printing: The new industrial revolution. Bus. Horiz. 2012, 55, 155-162. [CrossRef]

27. Javaid, M.; Haleem, A. Additive manufacturing applications in medical cases: A literature based review. Alex. J. Med. 2018, 54, 411-422. [CrossRef]

28. Miri, A.K.; Khalilpour, A.; Cecen, B.; Maharjan, S.; Shin, S.R.; Khademhosseini, A. Multiscale bioprinting of vascularized models. Biomaterials 2019, 198, 204-216. [CrossRef]

29. Noor, N.; Shapira, A.; Edri, R.; Gal, I.; Wertheim, L.; Dvir, T. 3D Printing of Personalized Thick and Perfusable Cardiac Patches and Hearts. Adv. Sci. 2019, 6, 1900344. [CrossRef]

30. Chen, Y.; Zhang, J.; Liu, X.; Wang, S.; Tao, J.; Huang, Y.; Wu, W.; Li, Y.; Zhou, K.; Wei, X.; et al. Noninvasive in vivo 3D bioprinting. Sci. Adv. 2020, 6, eaba7406. [CrossRef]

31. Javaid, M.; Haleem, A. Current status and applications of additive manufacturing in dentistry: A literature-based review. J. Oral Biol. Craniofacial Res. 2019, 9, 179-185. [CrossRef]

32. Jasiuk, I.; Abueidda, D.W.; Kozuch, C.; Pang, S.; Su, F.Y.; McKittrick, J. An Overview on Additive Manufacturing of Polymers. JOM 2018, 70, 275-283. [CrossRef]

33. Saroia, J.; Wang, Y.; Wei, Q.; Lei, M.; Li, X.; Guo, Y.; Zhang, K. A review on 3D printed matrix polymer composites: Its potential and future challenges. Int. J. Adv. Manuf. Technol. 2020, 106, 1695-1721. [CrossRef]

34. Gao, W.; Zhang, Y.; Ramanujan, D.; Ramani, K.; Chen, Y.; Williams, C.B.; Wang, C.C.L.; Shin, Y.C.; Zhang, S.; Zavattieri, P.D. The status, challenges, and future of additive manufacturing in engineering. Comput. Aided Des. 2015, 69, 65-89. [CrossRef]

35. Doubrovski, Z.; Verlinden, J.C.; Geraedts, J.M.P. Optimal Design for Additive Manufacturing: Opportunities and Challenges. In Proceedings of the ASME 2011 International Design Engineering Technical Conferences and Computers and Information in Engineering Conference, Washington, DC, USA, 28-31 August 2011; pp. 635-646.

36. Hashemi Sanatgar, R.; Campagne, C.; Nierstrasz, V. Investigation of the adhesion properties of direct 3D printing of polymers and nanocomposites on textiles: Effect of FDM printing process parameters. Appl. Surf. Sci. 2017, 403, 551-563. [CrossRef]

37. Zaldivar, R.; Witkin, D.; McLouth, T.; Patel, D.; Schmitt, K.; Nokes, J. Influence of processing and orientation print effects on the mechanical and thermal behavior of 3D-Printed ULTEM ${ }^{\circledR} 9085$ Material. Addit. Manuf. 2017, 13, 71-80. [CrossRef]

38. Wu, H.; Sulkis, M.; Driver, J.; Saade-Castillo, A.; Thompson, A.; Koo, J.H. Multi-functional ULTEM ${ }^{\mathrm{TM}} 1010$ composite filaments for additive manufacturing using Fused Filament Fabrication (FFF). Addit. Manuf. 2018, 24, 298-306. [CrossRef]

39. Ahn, S.H.; Lee, C.S.; Jeong, W. Development of translucent FDM parts by post-processing. Rapid Prototyp. J. 2004, 10, 218-224. [CrossRef]

40. Cahyadi, W. Mechanical Properties of 3D Printed Acrylonitrile Styrene Acrylate. Electronic Theses and Dissertations. 2019. 3187. Available online: https://openprairie.sdstate.edu/etd/3187 (accessed on 11 November 2020).

41. Novakova-Marcincinova, L.; Novak-Marcincin, J.; Barna, J.; Torok, J. Special materials used in FDM rapid prototyping technology application. In Proceedings of the 2012 IEEE 16th International Conference on Intelligent Engineering Systems (INES), Lisbon, Portugal, 13-15 June 2012; pp. 73-76.

42. Sheth, S.; Taylor, R.M.; Adluru, H. Numerical investigation of stiffness properties of fdm parts as a function of raster orientation. In Proceedings of the 28th Annual International Solid Freeform Fabrication Symposium-An Additive Manufacturing Conference, Austin, TX, USA, 7-9 August 2017; pp. 1112-1120.

43. Sun, Q.; Rizvi, G.; Bellehumeur, C.; Gu, P. Effect of processing conditions on the bonding quality of FDM polymer filaments. Rapid Prototyp. J. 2008, 14, 72-80. [CrossRef]

44. Gajdoš, I.; Slota, J. Influence of printing conditions on structure in FDM prototypes. Teh. Vjesn. 2013, 20, $231-236$.

45. Espalin, D.; Ramirez, J.A.; Medina, F.; Wicker, R. Multi-material, multi-technology FDM: Exploring build process variations. Rapid Prototyp. J. 2014, 20, 236-244. [CrossRef] 
46. Chen, M.Y.; Skewes, J.; Woodruff, M.A.; Dasgupta, P.; Rukin, N.J. Multi-colour extrusion fused deposition modelling: A low-cost 3D printing method for anatomical prostate cancer models. Sci. Rep. 2020, 10, 1-5.

47. Hoskins, T.J.; Dearn, K.D.; Kukureka, S.N. Mechanical performance of PEEK produced by additive manufacturing. Polym. Test. 2018, 70, 511-519. [CrossRef]

48. Udofia, E.N.; Zhou, W. A Guiding Framework for Microextrusion Additive Manufacturing. J. Manuf. Sci. Eng. 2019, 141. [CrossRef]

49. Cicala, G.; Ognibene, G.; Portuesi, S.; Blanco, I.; Rapisarda, M.; Pergolizzi, E.; Recca, G. Comparison of Ultem 9085 used in fused deposition modelling (FDM) with polytherimide blends. Materials 2018, 11, 285. [CrossRef] [PubMed]

50. Valerga, A.P.; Batista, M.; Salguero, J.; Girot, F. Influence of PLA filament conditions on characteristics of FDM parts. Materials 2018, 11, 1322. [CrossRef] [PubMed]

51. Santoliquido, O.; Colombo, P.; Ortona, A. Additive Manufacturing of ceramic components by Digital Light Processing: A comparison between the "bottom-up" and the "top-down" approaches. J. Eur. Ceram. Soc. 2019, 39, 2140-2148. [CrossRef]

52. Layani, M.; Wang, X.; Magdassi, S. Novel materials for 3D printing by photopolymerization. Adv. Mater. 2018, 30, 1706344. [CrossRef] [PubMed]

53. Jiao, Z.; Wang, C.; Yang, Q.; Wang, X. Preparation and characterization of UV-curable urethane acrylate oligomers modified with cycloaliphatic epoxide resin. J. Coat. Technol. Res. 2018, 15, 251-258. [CrossRef]

54. Sangermano, M.; Carbonaro, W.; Malucelli, G.; Priola, A. UV-Cured Interpenetrating Acrylic-Epoxy Polymer Networks: Preparation and Characterization. Macromol. Mater. Eng. 2008, 293, 515-520. [CrossRef]

55. Loos, M.; Coelho, L.; Pezzin, S.; Amico, S. The effect of acetone addition on the properties of epoxy. Polim. Cienc. E Tecnol. Polim. 2008, 18. [CrossRef]

56. Hong, B.T.; Shin, K.S.; Kim, D.S. Ultraviolet-curing behavior of an epoxy acrylate resin system. J. Appl. Polym. Sci. 2005, 98, 1180-1185. [CrossRef]

57. Lovell, L.G.; Lu, H.; Elliott, J.E.; Stansbury, J.W.; Bowman, C.N. The effect of cure rate on the mechanical properties of dental resins. Dent. Mater. 2001, 17, 504-511. [CrossRef]

58. Chen, K.; Kuang, X.; Li, V.; Kang, G.; Qi, H.J. Fabrication of tough epoxy with shape memory effects by UV-assisted direct-ink write printing. Soft Matter 2018, 14, 1879-1886. [CrossRef]

59. Zhang, Z.-c.; Li, P.-1.; Chu, F.-t.; Shen, G. Influence of the three-dimensional printing technique and printing layer thickness on model accuracy. J. Orofac. Orthop. Fortschr. Der Kieferorthopädie 2019, 80, 194-204. [CrossRef] [PubMed]

60. Watters, M.P.; Bernhardt, M.L. Curing parameters to improve the mechanical properties of stereolithographic printed specimens. Rapid Prototyp. J. 2018, 24, 46-51. [CrossRef]

61. Yankov, E.; Nikolova, M.P. Comparison of the accuracy of 3D printed prototypes using the stereolithography (SLA) method with the digital CAD models. In Proceedings of the MATEC Web of Conferences, Cluj-Napoca, Romania, 12-13 October 2017; p. 02014.

62. de Camargo, E.J.; Moreschi, E.; Baseggio, W.; Cury, J.A.; Pascotto, R.C. Composite depth of cure using four polymerization techniques. J. Appl. Oral Sci. 2009, 17, 446-450. [CrossRef] [PubMed]

63. Shen, M.; Zhao, W.; Xing, B.; Sing, Y.; Gao, S.; Wang, C.; Zhao, Z. Effects of exposure time and printing angle on the curing characteristics and flexural strength of ceramic samples fabricated via digital light processing. Ceram. Int. 2020, 46, 24379-24384. [CrossRef]

64. Wu, D.; Zhao, Z.; Zhang, Q.; Qi, H.J.; Fang, D. Mechanics of shape distortion of DLP 3D printed structures during UV post-curing. Soft Matter 2019, 15, 6151-6159. [CrossRef]

65. Wu, C.; Yi, R.; Liu, Y.-J.; He, Y.; Wang, C.C. Delta DLP 3D printing with large size. In Proceedings of the 2016 IEEE/RSJ International Conference on Intelligent Robots and Systems (IROS), Daejeon, Korea, 9-14 October 2016; pp. 2155-2160.

66. Yi, R.; Wu, C.; Liu, Y.-J.; He, Y.; Wang, C.C. Delta DLP 3-D printing of large models. IEEE Trans. Autom. Sci. Eng. 2017, 15, 1193-1204. [CrossRef]

67. Maruo, S.; Fourkas, J.T. Recent progress in multiphoton microfabrication. Laser Photonics Rev. 2008, 2, $100-111$. [CrossRef]

68. Jonušauskas, L.; Gailevičius, D.; Mikoliūnaitè, L.; Sakalauskas, D.; Šakirzanovas, S.; Juodkazis, S.; Malinauskas, M. Optically Clear and Resilient Free-Form $\mu$-Optics 3D-Printed via Ultrafast Laser Lithography. Materials 2017, 10, 12. [CrossRef] 
69. Farsari, M.; Vamvakaki, M.; Chichkov, B.N. Multiphoton polymerization of hybrid materials. J. Opt. 2010, 12, 124001. [CrossRef]

70. Zhang, Y.-L.; Chen, Q.-D.; Xia, H.; Sun, H.-B. Designable 3D nanofabrication by femtosecond laser direct writing. Nano Today 2010, 5, 435-448. [CrossRef]

71. Ciuciu, A.I.; Cywiński, P.J. Two-photon polymerization of hydrogels versatile solutions to fabricate well-defined 3D structures. RSC Adv. 2014, 4, 45504-45516. [CrossRef]

72. Doherty, R.P.; Varkevisser, T.; Teunisse, M.; Hoecht, J.; Ketzetzi, S.; Ouhajji, S.; Kraft, D.J. Catalytically propelled 3D printed colloidal microswimmers. Soft Matter 2020. [CrossRef] [PubMed]

73. Shirazi, S.F.S.; Gharehkhani, S.; Mehrali, M.; Yarmand, H.; Metselaar, H.S.C.; Kadri, N.A.; Osman, N.A.A. A review on powder-based additive manufacturing for tissue engineering: Selective laser sintering and inkjet 3D printing. Sci. Technol. Adv. Mater. 2015, 16, 033502. [CrossRef] [PubMed]

74. Eshraghi, S.; Das, S. Mechanical and microstructural properties of polycaprolactone scaffolds with one-dimensional, two-dimensional, and three-dimensional orthogonally oriented porous architectures produced by selective laser sintering. Acta Biomater. 2010, 6, 2467-2476. [CrossRef] [PubMed]

75. Vaezi, M.; Seitz, H.; Yang, S. A review on 3D micro-additive manufacturing technologies. Int. J. Adv. Manuf. Technol. 2013, 67, 1721-1754. [CrossRef]

76. Shuai, C.; Zhuang, J.; Peng, S.; Wen, X. Inhibition of phase transformation from $\beta$-to $\alpha$-tricalcium phosphate with addition of poly (L-lactic acid) in selective laser sintering. Rapid Prototyp. J. 2014, 20, 369-376. [CrossRef]

77. Schmid, M.; Amado, A.; Wegener, K. Polymer powders for selective laser sintering (SLS). In Proceedings of the AIP Conference Proceedings, Cleveland, OH, USA, 6-12 June 2014; Volume 1664, p. 160009.

78. Lee, H.; Lim, C.H.J.; Low, M.J.; Tham, N.; Murukeshan, V.M.; Kim, Y.-J. Lasers in additive manufacturing: A review. Int. J. Precis. Eng. Manuf. Green Technol. 2017, 4, 307-322. [CrossRef]

79. Kudelski, R.; Cieslik, J.; Kulpa, M.; Dudek, P.; Zagorski, K.; Rumin, R. Comparison of cost, material and time usage in FDM and SLS 3D printing methods. In Proceedings of the 2017 XIIIth International Conference on Perspective Technologies and Methods in MEMS Design (MEMSTECH), Lviv, Ukraine, 20-23 April 2017; pp. 12-14.

80. Cazón, A.; Morer, P.; Matey, L. PolyJet technology for product prototyping: Tensile strength and surface roughness properties. Proc. Inst. Mech. Eng. Part B: J. Eng. Manuf. 2014, 228, 1664-1675.

81. Miyanaji, H.; Momenzadeh, N.; Yang, L. Effect of printing speed on quality of printed parts in Binder Jetting Process. Addit. Manuf. 2018, 20,1-10. [CrossRef]

82. Singh, R. Process capability study of polyjet printing for plastic components. J. Mech. Sci. Technol. 2011, 25, 1011-1015. [CrossRef]

83. Barclift, M.W.; Williams, C.B. Examining variability in the mechanical properties of parts manufactured via polyjet direct 3D printing. In Proceedings of the International Solid Freeform Fabrication Symposium, Austin, TX, USA, 6-8 August 2012; pp. 6-8.

84. Gaynor, A.T.; Meisel, N.A.; Williams, C.B.; Guest, J.K. Multiple-material topology optimization of compliant mechanisms created via PolyJet three-dimensional printing. J. Manuf. Sci. Eng. 2014, 136, 061015:1-061015:10. [CrossRef]

85. Ibrahim, D.; Broilo, T.L.; Heitz, C.; de Oliveira, M.G.; de Oliveira, H.W.; Nobre, S.M.W.; dos Santos Filho, J.H.G.; Silva, D.N. Dimensional error of selective laser sintering, three-dimensional printing and PolyJet ${ }^{\mathrm{TM}}$ models in the reproduction of mandibular anatomy. J. Cranio Maxillofac. Surg. 2009, 37, 167-173. [CrossRef] [PubMed]

86. Tan, W.S.; Suwarno, S.R.; An, J.; Chua, C.K.; Fane, A.G.; Chong, T.H. Comparison of solid, liquid and powder forms of 3D printing techniques in membrane spacer fabrication. J. Membr. Sci. 2017, 537, 283-296. [CrossRef]

87. Subbiah, R.; Arun, A.; Lakshmi, A.A.; Naga Sai Harika, A.; Ram, N.; Sateesh, N. Experimental Study of Wear Behaviour on Al-2014 Alloy Coated with Thermal Spray HVOF (High Velocity Oxy-Fuel) and Plasma Spray Process-A Review. Mater. Today Proc. 2019, 18, 5151-5157. [CrossRef]

88. Park, J.; Tari, M.J.; Hahn, H.T. Characterization of the laminated object manufacturing (LOM) process. Rapid Prototyp. J. 2000, 6, 36-50. [CrossRef]

89. Mueller, B.; Kochan, D. Laminated object manufacturing for rapid tooling and patternmaking in foundry industry. Comput. Ind. 1999, 39, 47-53. [CrossRef]

90. Paul, B.K.; Voorakarnam, V. Effect of layer thickness and orientation angle on surface roughness in laminated object manufacturing. J. Manuf. Process. 2001, 3, 94-101. [CrossRef] 
91. Ahn, D.; Kweon, J.-H.; Choi, J.; Lee, S. Quantification of surface roughness of parts processed by laminated object manufacturing. J. Mater. Process. Technol. 2012, 212, 339-346. [CrossRef]

92. Huang, Q.3D Printing Shrinkage Compensation Using Radial and Angular Layer Perimeter Point Information. U.S. Patent 9,886,526, 6 February 2018.

93. Gkartzou, E.; Koumoulos, E.P.; Charitidis, C.A. Production and 3D printing processing of bio-based thermoplastic filament. Manuf. Rev. 2017, 4, 1. [CrossRef]

94. Ma, G.; Li, Z.; Wang, L.; Wang, F.; Sanjayan, J. Mechanical anisotropy of aligned fiber reinforced composite for extrusion-based 3D printing. Constr. Build. Mater. 2019, 202, 770-783. [CrossRef]

95. Akhoundi, B.; Behravesh, A.H.; Bagheri Saed, A. Improving mechanical properties of continuous fiber-reinforced thermoplastic composites produced by FDM 3D printer. J. Reinf. Plast. Compos. 2019, 38, 99-116. [CrossRef]

96. Heidari-Rarani, M.; Rafiee-Afarani, M.; Zahedi, A. Mechanical characterization of FDM 3D printing of continuous carbon fiber reinforced PLA composites. Compos. Part B Eng. 2019, 175, 107147. [CrossRef]

97. Imeri, A.; Russell, N.; Rust, J.; Sahin, S.; Fidan, I. MAKER: 3D Printing as an Alternative to Fabricate the Motorsports Parts. In Proceedings of the 2017 ASEE Annual Conference Proceedings, Columbus, OH, USA, 24-28 June 2017. [CrossRef]

98. Hofstätter, T.; Pedersen, D.B.; Tosello, G.; Hansen, H.N. Challenges and opportunities of fibre-reinforced polymers in additive manufacturing with focus on industrial applications. In Proceedings of the Joint Special Interest Group Meeting between EUSPEN and ASPE: Dimensional Accuracy and Surface Finish in Additive Manufacturing, Leuven, Belgium, 10-11 October 2017; pp. 10-11.

99. Farina, I.; Fabbrocino, F.; Carpentieri, G.; Modano, M.; Amendola, A.; Goodall, R.; Feo, L.; Fraternali, F. On the reinforcement of cement mortars through $3 \mathrm{D}$ printed polymeric and metallic fibers. Compos. Part B Eng. 2016, 90, 76-85. [CrossRef]

100. Ning, F.; Cong, W.; Hu, Y.; Wang, H. Additive manufacturing of carbon fiber-reinforced plastic composites using fused deposition modeling: Effects of process parameters on tensile properties. J. Compos. Mater. 2017, 51, 451-462. [CrossRef]

101. Zhong, W.; Li, F.; Zhang, Z.; Song, L.; Li, Z. Short fiber reinforced composites for fused deposition modeling. Mater. Sci. Eng. A 2001, 301, 125-130. [CrossRef]

102. Ivey, M.; Melenka, G.W.; Carey, J.P.; Ayranci, C. Characterizing short-fiber-reinforced composites produced using additive manufacturing. Adv. Manuf. Polym. Compos. Sci. 2017, 3, 81-91. [CrossRef]

103. Li, N.; Li, Y.; Liu, S. Rapid prototyping of continuous carbon fiber reinforced polylactic acid composites by 3D printing. J. Mater. Process. Technol. 2016, 238, 218-225. [CrossRef]

104. Liao, G.; Li, Z.; Cheng, Y.; Xu, D.; Zhu, D.; Jiang, S.; Guo, J.; Chen, X.; Xu, G.; Zhu, Y. Properties of oriented carbon fiber/polyamide 12 composite parts fabricated by fused deposition modeling. Mater. Des. 2018, 139, 283-292. [CrossRef]

105. Han, X.; Yang, D.; Yang, C.; Spintzyk, S.; Scheideler, L.; Li, P.; Li, D.; Geis-Gerstorfer, J.; Rupp, F. Carbon Fiber Reinforced PEEK Composites Based on 3D-Printing Technology for Orthopedic and Dental Applications. J. Clin. Med. 2019, 8, 240. [CrossRef]

106. Carneiro, O.S.; Silva, A.F.; Gomes, R. Fused deposition modeling with polypropylene. Mater. Des. 2015, 83, 768-776. [CrossRef]

107. Sodeifian, G.; Ghaseminejad, S.; Yousefi, A.A. Preparation of polypropylene/short glass fiber composite as Fused Deposition Modeling (FDM) filament. Results Phys. 2019, 12, 205-222. [CrossRef]

108. Dickson, A.N.; Barry, J.N.; McDonnell, K.A.; Dowling, D.P. Fabrication of continuous carbon, glass and Kevlar fibre reinforced polymer composites using additive manufacturing. Addit. Manuf. 2017, 16, 146-152. [CrossRef]

109. Mohammadizadeh, M.; Fidan, I.; Allen, M.; Imeri, A. Creep behavior analysis of additively manufactured fiber-reinforced components. Int. J. Adv. Manuf. Technol. 2018, 99, 1225-1234. [CrossRef]

110. Imeri, A.; Fidan, I. Fatigue behaviors of fiber-reinforced composite 3D printing. In Fatigue Life Prediction of Composites and Composite Structures; Elsevier: Amsterdam, The Netherlands, 2020; pp. 335-348.

111. Imeri, A.; Fidan, I.; Allen, M.; Wilson, D.; Canfield, S. Fatigue analysis of the fiber reinforced additively manufactured objects. Int. J. Adv. Manuf. Technol. 2018, 98, 2717-2724. [CrossRef]

112. Torrado Perez, A.R.; Roberson, D.A.; Wicker, R.B. Fracture Surface Analysis of 3D-Printed Tensile Specimens of Novel ABS-Based Materials. J. Fail. Anal. Prev. 2014, 14, 343-353. [CrossRef] 
113. Depuydt, D.; Balthazar, M.; Hendrickx, K.; Six, W.; Ferraris, E.; Desplentere, F.; Ivens, J.; Van Vuure, A.W. Production and characterization of bamboo and flax fiber reinforced polylactic acid filaments for fused deposition modeling (FDM). Polym. Compos. 2019, 40, 1951-1963. [CrossRef]

114. Matsuzaki, R.; Ueda, M.; Namiki, M.; Jeong, T.-K.; Asahara, H.; Horiguchi, K.; Nakamura, T.; Todoroki, A.; Hirano, Y. Three-dimensional printing of continuous-fiber composites by in-nozzle impregnation. Sci. Rep. 2016, 6, 23058. [CrossRef]

115. Kariz, M.; Sernek, M.; Obućina, M.; Kuzman, M.K. Effect of wood content in FDM filament on properties of 3D printed parts. Mater. Today Commun. 2018, 14, 135-140. [CrossRef]

116. Navarrete, J.I.M.; Hidalgo-Salazar, M.A.; Nunez, E.E.; Arciniegas, A.J.R. Thermal and mechanical behavior of biocomposites using additive manufacturing. Int. J. Interact. Des. Manuf. 2018, 12, 449-458. [CrossRef]

117. Stoof, D.; Pickering, K. Sustainable composite fused deposition modelling filament using recycled pre-consumer polypropylene. Compos. Part B Eng. 2018, 135, 110-118. [CrossRef]

118. Chen, X.; Guo, Q.; Mi, Y. Bamboo fiber-reinforced polypropylene composites: A study of the mechanical properties. J. Appl. Polym. Sci. 1998, 69, 1891-1899. [CrossRef]

119. Milosevic, M.; Stoof, D.; Pickering, K. Characterizing the mechanical properties of fused deposition modelling natural fiber recycled polypropylene composites. J. Compos. Sci. 2017, 1, 7. [CrossRef]

120. Palmero, E.M.; Casaleiz, D.; de Vicente, J.; Hernández-Vicen, J.; López-Vidal, S.; Ramiro, E.; Bollero, A. Composites based on metallic particles and tuned filling factor for 3D-printing by Fused Deposition Modeling. Compos. Part A Appl. Sci. Manuf. 2019, 124, 105497. [CrossRef]

121. Ryder, M.A.; Lados, D.A.; Iannacchione, G.S.; Peterson, A.M. Fabrication and properties of novel polymer-metal composites using fused deposition modeling. Compos. Sci. Technol. 2018, 158, 43-50. [CrossRef]

122. Bedi, P.; Singh, R.; Ahuja, I. Effect of SiC/Al2O3 particle size reinforcement in recycled LDPE matrix on mechanical properties of FDM feed stock filament. Virtual Phys. Prototyp. 2018, 13, 246-254. [CrossRef]

123. Singh, R.; Bedi, P.; Fraternali, F.; Ahuja, I. Effect of single particle size, double particle size and triple particle size Al2O3 in Nylon-6 matrix on mechanical properties of feed stock filament for FDM. Compos. Part B Eng. 2016, 106, 20-27. [CrossRef]

124. Restrepo, J.J.; Colorado, H.A. Additive manufacturing of composites made of epoxy resin with magnetite particles fabricated with the direct ink writing technique. J. Compos. Mater. 2020, 54, 647-657. [CrossRef]

125. Saha, M.C.; Nilufar, S. Nanoclay-reinforced syntactic foams: Flexure and thermal behavior. Polym. Compos. 2010, 31, 1332-1342. [CrossRef]

126. Saha, M.C.; Nilufar, S.; Major, M.; Jeelani, S. Processing and performance evaluation of hollow microspheres filled epoxy composites. Polym. Compos. 2008, 29, 293-301. [CrossRef]

127. Singh, A.K.; Saltonstall, B.; Patil, B.; Hoffmann, N.; Doddamani, M.; Gupta, N. Additive manufacturing of syntactic foams: Part 2: Specimen printing and mechanical property characterization. JOM 2018, 70, 310-314. [CrossRef]

128. Singh, A.K.; Patil, B.; Hoffmann, N.; Saltonstall, B.; Doddamani, M.; Gupta, N. Additive manufacturing of syntactic foams: Part 1: Development, properties, and recycling potential of filaments. JOM 2018, 70, 303-309. [CrossRef]

129. Singh, A.K.; Deptula, A.J.; Anawal, R.; Doddamani, M.; Gupta, N. Additive manufacturing of three-phase syntactic foams containing glass microballoons and air pores. JOM 2019, 71, 1520-1527. [CrossRef]

130. Çantı, E.; Aydın, M. Effects of micro particle reinforcement on mechanical properties of 3D printed parts. Rapid Prototyp. J. 2018, 24, 171-176. [CrossRef]

131. Kalsoom, U.; Peristyy, A.; Nesterenko, P.N.; Paull, B. A 3D printable diamond polymer composite: A novel material for fabrication of low cost thermally conducting devices. RSC Adv. 2016, 6, 38140-38147. [CrossRef]

132. Hwang, S.; Reyes, E.I.; Moon, K.-S.; Rumpf, R.C.; Kim, N.S. Thermo-mechanical Characterization of Metal/Polymer Composite Filaments and Printing Parameter Study for Fused Deposition Modeling in the 3D Printing Process. J. Electron. Mater. 2015, 44, 771-777. [CrossRef]

133. Khatri, B.; Lappe, K.; Habedank, M.; Mueller, T.; Megnin, C.; Hanemann, T. Fused deposition modeling of abs-barium titanate composites: A simple route towards tailored dielectric devices. Polymers 2018, 10, 666. [CrossRef]

134. Masood, S.H.; Song, W.Q. Thermal characteristics of a new metal/polymer material for FDM rapid prototyping process. Assem. Autom. 2005, 25, 309-315. [CrossRef] 
135. Abdullah, A.M.; Tuan Rahim, T.N.A.; Mohamad, D.; Akil, H.M.; Rajion, Z.A. Mechanical and physical properties of highly ZrO2 / $\beta$-TCP filled polyamide 12 prepared via fused deposition modelling (FDM) 3D printer for potential craniofacial reconstruction application. Mater. Lett. 2017, 189, 307-309. [CrossRef]

136. Joyee, E.B.; Lu, L.; Pan, Y. Analysis of mechanical behavior of 3D printed heterogeneous particle-polymer composites. Compos. Part B Eng. 2019, 173, 106840. [CrossRef]

137. Chung, H.; Das, S. Processing and properties of glass bead particulate-filled functionally graded Nylon-11 composites produced by selective laser sintering. Mater. Sci. Eng. A 2006, 437, 226-234. [CrossRef]

138. Song, S.Y.; Park, M.S.; Lee, J.W.; Yun, J.S. A study on the rheological and mechanical properties of photo-curable ceramic/polymer composites with different silane coupling agents for SLA 3D printing technology. Nanomaterials 2018, 8, 93. [CrossRef] [PubMed]

139. Han, Y.; Wang, F.; Wang, H.; Jiao, X.; Chen, D. High-strength boehmite-acrylate composites for 3D printing: Reinforced filler-matrix interactions. Compos. Sci. Technol. 2018, 154, 104-109. [CrossRef]

140. Mubarak, S.; Dhamodharan, D.; Kale, M.B.; Divakaran, N.; Senthil, T.; Wu, L.; Wang, J. A Novel Approach to Enhance Mechanical and Thermal Properties of SLA 3D Printed Structure by Incorporation of Metal-Metal Oxide Nanoparticles. Nanomaterials 2020, 10, 217. [CrossRef] [PubMed]

141. Schmitz, A. Effect of Three-Dimensional Printing With Nanotubes on Impact and Fatigue Resistance. J. Eng. Mater. Technol. 2020, 142, 024501:1-024501:5. [CrossRef]

142. Hmeidat, N.S.; Kemp, J.W.; Compton, B.G. High-strength epoxy nanocomposites for 3D printing. Compos. Sci. Technol. 2018, 160, 9-20. [CrossRef]

143. Zhu, D.; Ren, Y.; Liao, G.; Jiang, S.; Liu, F.; Guo, J.; Xu, G. Thermal and mechanical properties of polyamide 12/graphene nanoplatelets nanocomposites and parts fabricated by fused deposition modeling. J. Appl. Polym. Sci. 2017, 134, 45332. [CrossRef]

144. Richardson, M.J.; Wu, H.; Wilcox, T.J.; Broaddus, M.; Lin, P.C.; Krifa, M.; Koo, J.H. Flame Retardant Nylon 6 Nanocomposites for Fused Deposition Modelling (FDM) Applications. In Proceedings of the SAMPE Conference, Seattle, WA, USA, 22-25 May 2017.

145. Wu, H.; Kafi, A.; Kim, H.; Shah, R.; Bateman, S.; Koo, J. Additive manufacturing of flame-retardant polyamide 6 nanocomposites via fused filament fabrication (FFF). In Proceedings of the SAMPE Conference, Charlotte, NC, USA, 20-23 May 2019.

146. Sangermano, M.; Pinneri, S.; Calza, P.; Paganini, C. Photocatalytic activity of epoxy/CNT nanocomposite films. Macromol. Mater. Eng. 2012, 297, 353-358. [CrossRef]

147. Sangermano, M.; Marino, F.; Reuel, N.; Strano, M.S. Semiconducting Single-Walled Carbon Nanotubes as Radical Photoinitiators. Macromol. Chem. Phys. 2011, 212, 1469-1473. [CrossRef]

148. Gonzalez, G.; Chiappone, A.; Roppolo, I.; Fantino, E.; Bertana, V.; Perrucci, F.; Scaltrito, L.; Pirri, F.; Sangermano, M. Development of 3D printable formulations containing CNT with enhanced electrical properties. Polymer 2017, 109, 246-253. [CrossRef]

149. Lin, H.; Zhu, H.; Guo, H.; Yu, L. Microwave-absorbing properties of Co-filled carbon nanotubes. Mater. Res. Bull. 2008, 43, 2697-2702. [CrossRef]

150. Che, R.C.; Peng, L.M.; Duan, X.F.; Chen, Q.; Liang, X.L. Microwave absorption enhancement and complex permittivity and permeability of Fe encapsulated within carbon nanotubes. Adv. Mater. 2004, 16, 401-405. [CrossRef]

151. Zhao, D.-L.; Li, X.; Shen, Z.-M. Preparation and electromagnetic and microwave absorbing properties of Fe-filled carbon nanotubes. J. Alloys Compd. 2009, 471, 457-460. [CrossRef]

152. Liu, Z.; Bai, G.; Huang, Y.; Li, F.; Ma, Y.; Guo, T.; He, X.; Lin, X.; Gao, H.; Chen, Y. Microwave absorption of single-walled carbon nanotubes/soluble cross-linked polyurethane composites. J. Phys. Chem. C 2007, 111, 13696-13700. [CrossRef]

153. Fan, Z.; Luo, G.; Zhang, Z.; Zhou, L.; Wei, F. Electromagnetic and microwave absorbing properties of multi-walled carbon nanotubes/polymer composites. Mater. Sci. Eng. B 2006, 132, 85-89. [CrossRef]

154. Munir, A. Microwave radar absorbing properties of multiwalled carbon nanotubes polymer composites: A review. Adv. Polym. Technol. 2017, 36, 362-370. [CrossRef]

155. Tyagi, S.; Pandey, V.; Baskey, H.B.; Tyagi, N.; Garg, A.; Goel, S.; Shami, T.C. RADAR absorption study of BaFe12O19/ZnFe2O4/CNTs nanocomposite. J. Alloys Compd. 2018, 731, 584-590. [CrossRef]

156. Chen, S.H.; Kuo, W.S.; Yang, R.B. Microwave absorbing properties of a radar absorbing structure composed of carbon nanotube papers/glass fabric composites. Int. J. Appl. Ceram. Technol. 2019, 16, 2065-2072. [CrossRef] 
157. Savi, P.; Giorcelli, M.; Quaranta, S. Multi-walled carbon nanotubes composites for microwave absorbing applications. Appl. Sci. 2019, 9, 851. [CrossRef]

158. Zhang, Y.; Li, H.; Yang, X.; Zhang, T.; Zhu, K.; Si, W.; Liu, Z.; Sun, H. Additive manufacturing of carbon nanotube-photopolymer composite radar absorbing materials. Polym. Compos. 2018, 39, E671-E676. [CrossRef]

159. Bai, J.; Yuan, S.; Shen, F.; Zhang, B.; Chua, C.K.; Zhou, K.; Wei, J. Toughening of polyamide 11 with carbon nanotubes for additive manufacturing. Virtual Phys. Prototyp. 2017, 12, 235-240. [CrossRef]

160. Shofner, M.; Lozano, K.; Rodríguez-Macías, F.; Barrera, E. Nanofiber-reinforced polymers prepared by fused deposition modeling. J. Appl. Polym. Sci. 2003, 89, 3081-3090. [CrossRef]

161. Coppola, B.; Cappetti, N.; Maio, L.; Scarfato, P.; Incarnato, L. Layered silicate reinforced polylactic acid filaments for 3D printing of polymer nanocomposites. In Proceedings of the 2017 IEEE 3rd International Forum on Research and Technologies for Society and Industry (RTSI), Modena, Italy, 11-13 September 2017; pp. 1-4.

162. Francis, V.; Jain, P.K. Effect of stage-dependent addition of nanoparticles in additive manufacturing. J. Thermoplast. Compos. Mater. 2020, 33, 357-376. [CrossRef]

163. Ahn, S.H.; Montero, M.; Odell, D.; Roundy, S.; Wright Paul, K. Anisotropic material properties of fused deposition modeling ABS. Rapid Prototyp. J. 2002, 8, 248-257. [CrossRef]

164. Smith, W.C.; Dean, R.W. Structural characteristics of fused deposition modeling polycarbonate material. Polym. Test. 2013, 32, 1306-1312. [CrossRef]

165. Spoerk, M.; Savandaiah, C.; Arbeiter, F.; Traxler, G.; Cardon, L.; Holzer, C.; Sapkota, J. Anisotropic properties of oriented short carbon fibre filled polypropylene parts fabricated by extrusion-based additive manufacturing. Compos. Part A Appl. Sci. Manuf. 2018, 113, 95-104. [CrossRef]

166. Hmeidat, N.S.; Pack, R.C.; Talley, S.J.; Moore, R.B.; Compton, B.G. Mechanical anisotropy in polymer composites produced by material extrusion additive manufacturing. Addit. Manuf. 2020, 34, 101385. [CrossRef]

167. Chen, Q.; Mangadlao, J.D.; Wallat, J.; De Leon, A.; Pokorski, J.K.; Advincula, R.C. 3D Printing Biocompatible Polyurethane/Poly(lactic acid)/Graphene Oxide Nanocomposites: Anisotropic Properties. ACS Appl. Mater. Interfaces 2017, 9, 4015-4023. [CrossRef]

168. Sweeney, C.B.; Lackey, B.A.; Pospisil, M.J.; Achee, T.C.; Hicks, V.K.; Moran, A.G.; Teipel, B.R.; Saed, M.A.; Green, M.J. Welding of 3D-printed carbon nanotube-polymer composites by locally induced microwave heating. Sci. Adv. 2017, 3, e1700262. [CrossRef]

169. Sandoval, J.H.; Wicker, R.B. Functionalizing stereolithography resins: Effects of dispersed multi-walled carbon nanotubes on physical properties. Rapid Prototyp. J. 2006, 12, 292-303. [CrossRef]

170. Shofner, M.L.; Rodríguez-Macías, F.J.; Vaidyanathan, R.; Barrera, E.V. Single wall nanotube and vapor grown carbon fiber reinforced polymers processed by extrusion freeform fabrication. Compos. Part A Appl. Sci. Manuf. 2003, 34, 1207-1217. [CrossRef]

171. Caminero, M.Á.; Chacón, J.M.; García-Plaza, E.; Núñez, P.J.; Reverte, J.M.; Becar, J.P. Additive manufacturing of PLA-based composites using fused filament fabrication: Effect of graphene nanoplatelet reinforcement on mechanical properties, dimensional accuracy and texture. Polymers 2019, 11, 799. [CrossRef] [PubMed]

172. Dizon, J.R.C.; Chen, Q.; Valino, A.D.; Advincula, R.C. Thermo-mechanical and swelling properties of three-dimensional-printed poly (ethylene glycol) diacrylate/silica nanocomposites. MRS Commun. 2019, 9, 209-217. [CrossRef]

173. Moniruzzaman, M.; Winey, K.I. Polymer nanocomposites containing carbon nanotubes. Macromolecules 2006, 39, 5194-5205. [CrossRef]

174. Weng, Z.; Zhou, Y.; Lin, W.; Senthil, T.; Wu, L. Structure-property relationship of nano enhanced stereolithography resin for desktop SLA 3D printer. Compos. Part A Appl. Sci. Manuf. 2016, 88, 234-242. [CrossRef]

175. Wang, K.; Pan, W.; Liu, Z.; Wallin, T.J.; van Dover, G.; Li, S.; Giannelis, E.P.; Menguc, Y.; Shepherd, R.F. 3D Printing of Viscoelastic Suspensions via Digital Light Synthesis for Tough Nanoparticle-Elastomer Composites. Adv. Mater. 2020, 32, 2001646. [CrossRef] [PubMed]

176. Bae, C.-J. Integrally Cored Ceramic Investment Casting Mold Fabricated by Ceramic Stereolithography. Int. J. Appl. Ceram. Technol. 2008, 8, 1255-1262. [CrossRef] 
177. Ukaji, E.; Furusawa, T.; Sato, M.; Suzuki, N. The effect of surface modification with silane coupling agent on suppressing the photo-catalytic activity of fine $\mathrm{TiO}_{2}$ particles as inorganic UV filter. Appl. Surf. Sci. 2007, 254, 563-569. [CrossRef]

178. Sabzi, M.; Mirabedini, S.; Zohuriaan-Mehr, J.; Atai, M. Surface modification of $\mathrm{TiO}_{2}$ nano-particles with silane coupling agent and investigation of its effect on the properties of polyurethane composite coating. Prog. Org. Coat. 2009, 65, 222-228. [CrossRef]

179. Chen, Q.; Yakovlev, N.L. Adsorption and interaction of organosilanes on $\mathrm{TiO}_{2}$ nanoparticles. Appl. Surf. Sci. 2010, 257, 1395-1400. [CrossRef]

180. Zhao, J.; Milanova, M.; Warmoeskerken, M.M.C.G.; Dutschk, V. Surface modification of $\mathrm{TiO}_{2}$ nanoparticles with silane coupling agents. Colloids Surf. A Physicochem. Eng. Asp. 2012, 413, 273-279. [CrossRef]

181. Tomovska, R.; Daniloska, V.; Asua, J.M. Surface modification of $\mathrm{TiO}_{2}$ nanoparticles via photocataliticaly induced reaction: Influence of functionality of silane coupling agent. Appl. Surf. Sci. 2013, 264, 670-673. [CrossRef]

182. Dalle Vacche, S.; Oliveira, F.; Leterrier, Y.; Michaud, V.; Damjanovic, D.; Månson, J.-A.E. Effect of silane coupling agent on the morphology, structure, and properties of poly(vinylidene fluoride-trifluoroethylene)/BaTiO 3 composites. J. Mater. Sci. 2014, 49, 4552-4564. [CrossRef]

183. Luo, T.; Wei, X.; Huang, X.; Huang, L.; Yang, F. Tribological properties of Al2O3 nanoparticles as lubricating oil additives. Ceram. Int. 2014, 40, 7143-7149. [CrossRef]

184. Yun, J.S.; Park, T.-W.; Jeong, Y.H.; Cho, J.H. Development of ceramic-reinforced photopolymers for SLA 3D printing technology. Appl. Phys. A 2016, 122, 629. [CrossRef]

185. Song, S.Y.; Park, M.S.; Lee, J.W.; Yun, J.S. Improvement of dispersion stability and 3D-printing characteristics of ceramics in photopolymers by controlling the coating thickness of silane coupling agents. Mater. Chem. Phys. 2018, 216, 446-453. [CrossRef]

186. Sun, J.; Binner, J.; Bai, J. Effect of surface treatment on the dispersion of nano zirconia particles in non-aqueous suspensions for stereolithography. J. Eur. Ceram. Soc. 2019, 39, 1660-1667. [CrossRef]

187. Shan, S.; Kang, S.H.; Zhao, Z.; Fang, L.; Bertoldi, K. Design of planar isotropic negative Poisson's ratio structures. Extrem. Mech. Lett. 2015, 4, 96-102. [CrossRef]

188. Salit, V.; Weller, T. On the feasibility of introducing auxetic behavior into thin-walled structures. Acta Mater. 2009, 57, 125-135. [CrossRef]

189. Alderson, K.L.; Fitzgerald, A.; Evans, K.E. The strain dependent indentation resilience of auxetic microporous polyethylene. J. Mater. Sci. 2000, 35, 4039-4047. [CrossRef]

190. Coenen, V.L.; Alderson, K.L. Mechanisms of failure in the static indentation resistance of auxetic carbon fibre laminates. Phys. Status Solidi 2011, 248, 66-72. [CrossRef]

191. Carta, G.; Brun, M.; Baldi, A. Design of a porous material with isotropic negative Poisson's ratio. Mech. Mater. 2016, 97, 67-75. [CrossRef]

192. Li, S.; Hassanin, H.; Attallah, M.M.; Adkins, N.J.E.; Essa, K. The development of TiNi-based negative Poisson's ratio structure using selective laser melting. Acta Mater. 2016, 105, 75-83. [CrossRef]

193. Kuribayashi, K.; Tsuchiya, K.; You, Z.; Tomus, D.; Umemoto, M.; Ito, T.; Sasaki, M. Self-deployable origami stent grafts as a biomedical application of Ni-rich TiNi shape memory alloy foil. Mater. Sci. Eng. A 2006, 419, 131-137. [CrossRef]

194. Jacobs, S.; Coconnier, C.; DiMaio, D.; Scarpa, F.; Toso, M.; Martinez, J. Deployable auxetic shape memory alloy cellular antenna demonstrator: Design, manufacturing and modal testing. Smart Mater. Struct. 2012, 21, 075013. [CrossRef]

195. Kelkar, P.U.; Kim, H.S.; Cho, K.-H.; Kwak, J.Y.; Kang, C.-Y.; Song, H.-C. Cellular Auxetic Structures for Mechanical Metamaterials: A Review. Sensors 2020, 20, 3132. [CrossRef] [PubMed]

196. Alderson, K.; Alderson, A.; Smart, G.; Simkins, V.; Davies, P. Auxetic polypropylene fibres: Part 1-Manufacture and characterisation. Plast. Rubber Compos. 2002, 31, 344-349. [CrossRef]

197. Zhang, J.; Lu, G.; Wang, Z.; Ruan, D.; Alomarah, A.; Durandet, Y. Large deformation of an auxetic structure in tension: Experiments and finite element analysis. Compos. Struct. 2018, 184, 92-101. [CrossRef]

198. Sarvestani, H.Y.; Akbarzadeh, A.; Niknam, H.; Hermenean, K. 3D printed architected polymeric sandwich panels: Energy absorption and structural performance. Compos. Struct. 2018, 200, 886-909. [CrossRef]

199. Alomarah, A.; Masood, S.H.; Sbarski, I.; Faisal, B.; Gao, Z.; Ruan, D. Compressive properties of 3D printed auxetic structures: Experimental and numerical studies. Virtual Phys. Prototyp. 2020, 15, 1-21. [CrossRef] 
200. Wang, X.-T.; Chen, Y.-L.; Ma, L. The manufacture and characterization of composite three-dimensional re-entrant auxetic cellular structures made from carbon fiber reinforced polymer. J. Compos. Mater. 2018, 52, 3265-3273. [CrossRef]

201. Yuan, C.; Mu, X.; Dunn, C.K.; Haidar, J.; Wang, T.; Jerry Qi, H. Thermomechanically triggered two-stage pattern switching of 2D lattices for adaptive structures. Adv. Funct. Mater. 2018, 28, 1705727. [CrossRef]

202. Zhang, Q.; Yan, D.; Zhang, K.; Hu, G. Pattern transformation of heat-shrinkable polymer by three-dimensional (3D) printing technique. Sci. Rep. 2015, 5, 8936. [CrossRef] [PubMed]

203. Li, J.; Shim, J.; Deng, J.; Overvelde, J.T.; Zhu, X.; Bertoldi, K.; Yang, S. Switching periodic membranes via pattern transformation and shape memory effect. Soft Matter 2012, 8, 10322-10328. [CrossRef]

204. Liu, J.; Zhang, Y. Soft network materials with isotropic negative Poisson's ratios over large strains. Soft Matter 2018, 14, 693-703. [CrossRef]

205. Liu, J.; Zhang, Y. A Mechanics Model of Soft Network Materials With Periodic Lattices of Arbitrarily Shaped Filamentary Microstructures for Tunable Poisson's Ratios. J. Appl. Mech. 2018, 85. [CrossRef]

206. van Lith, R.; Baker, E.; Ware, H.; Yang, J.; Farsheed, A.C.; Sun, C.; Ameer, G. 3D-Printing Strong High-Resolution Antioxidant Bioresorbable Vascular Stents. Adv. Mater. Technol. 2016, 1, 1600138. [CrossRef]

207. Meeks, W.H. The Theory of Triply Periodic Minimal Surfaces. Indiana Univ. Math. J. 1990, 39, $877-936$. [CrossRef]

208. Evans, A.G.; Hutchinson, J.W.; Fleck, N.A.; Ashby, M.F.; Wadley, H.N.G. The topological design of multifunctional cellular metals. Prog. Mater. Sci. 2001, 46, 309-327. [CrossRef]

209. Wadley, H.N. Multifunctional periodic cellular metals. Philos. Trans. R. Soc. A Math. Phys. Eng. Sci. 2006, 364, 31-68. [CrossRef]

210. Cheng, L.; Liu, J.; Liang, X.; To, A.C. Coupling lattice structure topology optimization with design-dependent feature evolution for additive manufactured heat conduction design. Comput. Methods Appl. Mech. Eng. 2018, 332, 408-439. [CrossRef]

211. Sarakinioti, M.V.; Turrin, M.; Konstantinou, T.; Tenpierik, M.; Knaack, U. Developing an integrated 3D-printed façade with complex geometries for active temperature control. Mater. Today Commun. 2018, 15, 275-279. [CrossRef]

212. Liu, F.; Mao, Z.; Zhang, P.; Zhang, D.Z.; Jiang, J.; Ma, Z. Functionally graded porous scaffolds in multiple patterns: New design method, physical and mechanical properties. Mater. Des. 2018, 160, 849-860. [CrossRef]

213. Schoen, A.H. Infinite Periodic Minimal Surfaces without Self-Intersections; NASA Technical Reports; NASA Electronics Research Center: Cambridge, MA, USA, 1 May 1970.

214. Gan, Z.; Turner, M.D.; Gu, M. Biomimetic gyroid nanostructures exceeding their natural origins. Sci. Adv. 2016, 2, e1600084. [CrossRef] [PubMed]

215. Mille, C.; Tyrode, E.C.; Corkery, R.W. Inorganic chiral 3-D photonic crystals with bicontinuous gyroid structure replicated from butterfly wing scales. Chem. Commun. 2011, 47, 9873-9875. [CrossRef] [PubMed]

216. Abueidda, D.W.; Bakir, M.; Al-Rub, R.K.A.; Bergström, J.S.; Sobh, N.A.; Jasiuk, I. Mechanical properties of 3D printed polymeric cellular materials with triply periodic minimal surface architectures. Mater. Des. 2017, 122, 255-267. [CrossRef]

217. Abueidda, D.W.; Elhebeary, M.; Shiang, C.-S.A.; Pang, S.; Al-Rub, R.K.A.; Jasiuk, I.M. Mechanical properties of 3D printed polymeric Gyroid cellular structures: Experimental and finite element study. Mater. Des. 2019, 165, 107597. [CrossRef]

218. Al-Ketan, O.; Rezgui, R.; Rowshan, R.; Du, H.; Fang, N.X.; Abu Al-Rub, R.K. Microarchitected stretching-dominated mechanical metamaterials with minimal surface topologies. Adv. Eng. Mater. 2018, 20, 1800029. [CrossRef]

219. Li, D.; Liao, W.; Dai, N.; Xie, Y.M. Comparison of mechanical properties and energy absorption of sheet-based and strut-based gyroid cellular structures with graded densities. Materials 2019, 12, 2183. [CrossRef] [PubMed]

220. Jibril, L.; Ramírez, J.; Zaretski, A.V.; Lipomi, D.J. Single-Nanowire strain sensors fabricated by nanoskiving. Sens. Actuators A Phys. 2017, 263, 702-706. [CrossRef] [PubMed]

221. Khosravani, M.R.; Anders, D.; Weinberg, K. Influence of strain rate on fracture behavior of sandwich composite T-joints. Eur. J. Mech. A/Solids 2019, 78, 103821. [CrossRef] 
222. Chang, Y.-H.; Wang, K.; Wu, C.; Chen, Y.; Zhang, C.; Wang, B. A facile method for integrating direct-write devices into three-dimensional printed parts. Smart Mater. Struct. 2015, 24, 065008. [CrossRef]

223. Christ, J.F.; Aliheidari, N.; Ameli, A.; Pötschke, P. 3D printed highly elastic strain sensors of multiwalled carbon nanotube/thermoplastic polyurethane nanocomposites. Mater. Des. 2017, 131, 394-401. [CrossRef]

224. Dul, S.; Pegoretti, A.; Fambri, L. Fused Filament Fabrication of Piezoresistive Carbon Nanotubes Nanocomposites for Strain Monitoring. Front. Mater. 2020, 7. [CrossRef]

225. Kim, H.; Torres, F.; Islam, T.; Islam, D.; Chavez, L.A.; Garcia Rosales, C.A.; Wilburn, B.R.; Stewart, C.M.; Noveron, J.C.; Tseng, T.-L.B.; et al. Increased piezoelectric response in functional nanocomposites through multiwall carbon nanotube interface and fused-deposition modeling three-dimensional printing-CORRIGENDUM. Mrs Commun. 2017, 7, 974. [CrossRef]

226. Kim, K.; Park, J.; Suh, J.-h.; Kim, M.; Jeong, Y.; Park, I. 3D printing of multiaxial force sensors using carbon nanotube (CNT)/thermoplastic polyurethane (TPU) filaments. Sens. Actuators A Phys. 2017, 263, 493-500. [CrossRef]

227. Kwok, S.W.; Goh, K.H.H.; Tan, Z.D.; Tan, S.T.M.; Tjiu, W.W.; Soh, J.Y.; Ng, Z.J.G.; Chan, Y.Z.; Hui, H.K.; Goh, K.E.J. Electrically conductive filament for 3D-printed circuits and sensors. Appl. Mater. Today 2017, 9,167-175. [CrossRef]

228. Chizari, K.; Daoud, M.A.; Ravindran, A.R.; Therriault, D. 3D Printing of Highly Conductive Nanocomposites for the Functional Optimization of Liquid Sensors. Small 2016, 12, 6076-6082. [CrossRef]

229. Zhang, D.; Chi, B.; Li, B.; Gao, Z.; Du, Y.; Guo, J.; Wei, J. Fabrication of highly conductive graphene flexible circuits by 3D printing. Synth. Met. 2016, 217, 79-86. [CrossRef]

230. Sajid, M.; Gul, J.Z.; Kim, S.W.; Kim, H.B.; Na, K.H.; Choi, K.H. Development of 3D-printed embedded temperature sensor for both terrestrial and aquatic environmental monitoring robots. 3D Print. Addit. Manuf. 2018, 5, 160-169. [CrossRef]

231. Bali, C.; Brandlmaier, A.; Ganster, A.; Raab, O.; Zapf, J.; Hübler, A. Fully Inkjet-Printed Flexible Temperature Sensors Based on Carbon and PEDOT:PSS1. Mater. Today Proc. 2016, 3, 739-745. [CrossRef]

232. Liu, P.; Huang, S.H.; Mokasdar, A.; Zhou, H.; Hou, L. The impact of additive manufacturing in the aircraft spare parts supply chain: Supply chain operation reference (scor) model based analysis. Prod. Plan. Control 2014, 25, 1169-1181. [CrossRef]

233. Han, P. Additive Design and Manufacturing of Jet Engine Parts. Engineering 2017, 3, 648-652. [CrossRef]

234. Misra, A.K.; Grady, J.E.; Carter, R. Additive manufacturing of aerospace propulsion components. In Proceedings of the Additive Manufacturing for Small Manufacturers Conference, Pittsburgh, PA, USA, 1 October 2015.

235. Fischer, S.; Pfister, A.; Galitz, V.; Lyons, B.; Robinson, C.; Rupel, K.; Booth, R.; Kubiak, S. A high performance material for aerospace applications: Development of carbon fiber filled PEKK for laser sintering. In Proceedings of the 26th Annual International Solid Freeform Fabric Symposium, Austin, TX, USA, 10-12 August 2015; pp. 10-12.

236. Chuang, K.C.; Grady, J.E.; Draper, R.D.; Shin, E.-S.E.; Patterson, C.; Santelle, T.D. Additive manufacturing and characterization of Ultem polymers and composites. In Proceedings of the Composites and Advanced Materials Expo Conference, Dallas, TX, USA, 26-29 October 2015.

237. Goh, G.D.; Agarwala, S.; Goh, G.L.; Dikshit, V.; Sing, S.L.; Yeong, W.Y. Additive manufacturing in unmanned aerial vehicles (UAVs): Challenges and potential. Aerosp. Sci. Technol. 2017, 63, 140-151. [CrossRef]

238. Savastano, M.; Amendola, C.; Fabrizio, D.; Massaroni, E. 3-D printing in the spare parts supply chain: An explorative study in the automotive industry. In Digitally Supported Innovation; Springer: Berlin/Heidelberg, Germany, 2016; pp. 153-170.

239. Huang, Y.; Leu, M.C.; Mazumder, J.; Donmez, A. Additive Manufacturing: Current State, Future Potential, Gaps and Needs, and Recommendations. J. Manuf. Sci. Eng. 2015, 137. [CrossRef]

240. Buehler, E.; Comrie, N.; Hofmann, M.; McDonald, S.; Hurst, A. Investigating the Implications of 3D Printing in Special Education. Acm Trans. Access. Comput. 2016, 8, 1. [CrossRef]

241. Buehler, E.; Kane, S.K.; Hurst, A. ABC and 3D: Opportunities and obstacles to 3D printing in special education environments. In Proceedings of the 16th International ACM SIGACCESS Conference on Computers \& Accessibility, Rochester, New York, NY, USA, 20-22 October 2014; pp. 107-114.

242. AbouHashem, Y.; Dayal, M.; Savanah, S.; Štrkalj, G. The application of 3D printing in anatomy education. Med. Educ. Online 2015, 20, 29847. [CrossRef] 
243. Vaccarezza, M.; Papa, V. 3D printing: A valuable resource in human anatomy education. Anat Sci. Int. 2015, 90, 64-65. [CrossRef]

244. Jones, O.A.; Spencer, M.J. A simplified method for the 3D printing of molecular models for chemical education. J. Chem. Educ. 2018, 95, 88-96. [CrossRef]

245. Pinger, C.W.; Geiger, M.K.; Spence, D.M. Applications of 3D-Printing for Improving Chemistry Education. J. Chem. Educ. 2019, 97, 112-117. [CrossRef]

246. Shick, T.M.; Abdul Kadir, A.Z.; Ngadiman, N.H.A.; Ma'aram, A. A review of biomaterials scaffold fabrication in additive manufacturing for tissue engineering. J. Bioact. Compat. Polym. 2019, 34, 415-435. [CrossRef]

247. Jammalamadaka, U.; Tappa, K. Recent advances in biomaterials for 3D printing and tissue engineering. J. Funct. Biomater. 2018, 9, 22. [CrossRef] [PubMed]

248. Goyanes, A.; Buanz, A.B.; Basit, A.W.; Gaisford, S. Fused-filament 3D printing (3DP) for fabrication of tablets. Int. J. Pharm. 2014, 476, 88-92. [CrossRef] [PubMed]

249. Skowyra, J.; Pietrzak, K.; Alhnan, M.A. Fabrication of extended-release patient-tailored prednisolone tablets via fused deposition modelling (FDM) 3D printing. Eur. J. Pharm. Sci. 2015, 68, 11-17. [CrossRef] [PubMed]

250. Goyanes, A.; Buanz, A.B.; Hatton, G.B.; Gaisford, S.; Basit, A.W. 3D printing of modified-release aminosalicylate (4-ASA and 5-ASA) tablets. Eur. J. Pharm. Biopharm. 2015, 89, 157-162. [CrossRef]

251. Alhnan, M.A.; Okwuosa, T.C.; Sadia, M.; Wan, K.-W.; Ahmed, W.; Arafat, B. Emergence of 3D printed dosage forms: Opportunities and challenges. Pharm. Res. 2016, 33, 1817-1832. [CrossRef]

252. Guerra, A.J.; Ciurana, J. 3D-printed bioabsordable polycaprolactone stent: The effect of process parameters on its physical features. Mater. Des. 2018, 137, 430-437. [CrossRef]

253. Colpani, A.; Fiorentino, A.; Ceretti, E. Design and Fabrication of Customized Tracheal Stents by Additive Manufacturing. Procedia Manuf. 2020, 47, 1029-1035. [CrossRef]

254. Maroti, P.; Varga, P.; Abraham, H.; Falk, G.; Zsebe, T.; Meiszterics, Z.; Mano, S.; Csernatony, Z.; Rendeki, S.; Nyitrai, M. Printing orientation defines anisotropic mechanical properties in additive manufacturing of upper limb prosthetics. Mater. Res. Express 2018, 6, 035403. [CrossRef]

255. Vitali, A.; Regazzoni, D.; Rizzi, C.; Colombo, G. Design and Additive Manufacturing of Lower Limb Prosthetic Socket. In Proceedings of the ASME 2017 International Mechanical Engineering Congress and Exposition, Tampa, FL, USA, 3-9 November 2017.

256. Zadpoor, A.A.; Malda, J. Additive Manufacturing of Biomaterials, Tissues, and Organs; Springer: Berlin/Heidelberg, Germany, 2017.

257. Li, H.; Song, L.; Sun, J.; Ma, J.; Shen, Z. Dental ceramic prostheses by stereolithography-based additive manufacturing: Potentials and challenges. Adv. Appl. Ceram. 2019, 118, 30-36. [CrossRef]

258. Jindal, P.; Juneja, M.; Siena, F.L.; Bajaj, D.; Breedon, P. Mechanical and geometric properties of thermoformed and 3D printed clear dental aligners. Am. J. Orthod. Dentofac. Orthop. 2019, 156, 694-701. [CrossRef]

259. Revilla-León, M.; Sadeghpour, M.; Özcan, M. An update on applications of 3D printing technologies used for processing polymers used in implant dentistry. Odontology 2020, 108, 331-338. [CrossRef] [PubMed]

260. Hladky-Hennion, A.-C. Phononic crystal (PC) applications of ATILA. In Applications of ATILA FEM Software to Smart Materials; Elsevier: Amsterdam, The Netherlands, 2013; pp. 190-203.

261. Liu, Z.-F.; Wu, B.; He, C.-F. The properties of optimal two-dimensional phononic crystals with different material contrasts. Smart Mater. Struct. 2016, 25, 095036. [CrossRef]

262. Wang, Y.-F.; Wang, Y.-Z.; Wu, B.; Chen, W.; Wang, Y.-S. Tunable and active phononic crystals and metamaterials. Appl. Mech. Rev. 2020, 72, 040801:1-040801:35. [CrossRef]

263. An, X.; Lai, C.; He, W.; Fan, H. Three-dimensional meta-truss lattice composite structures with vibration isolation performance. Extrem. Mech. Lett. 2019, 33, 100577. [CrossRef]

264. An, X.; Lai, C.; Fan, H.; Zhang, C. 3D acoustic metamaterial-based mechanical metalattice structures for low-frequency and broadband vibration attenuation. Int. J. Solids Struct. 2020, 191-192, 293-306. [CrossRef]

265. Li, Y.; Jiang, X.; Li, R.-Q.; Liang, B.; Zou, X.-Y.; Yin, L.-L.; Cheng, J.-C. Experimental realization of full control of reflected waves with subwavelength acoustic metasurfaces. Phys. Rev. Appl. 2014, 2, 064002. [CrossRef]

266. Zigoneanu, L.; Popa, B.-I.; Cummer, S.A. Three-dimensional broadband omnidirectional acoustic ground cloak. Nat. Mater. 2014, 13, 352-355. [CrossRef]

267. Abueidda, D.W.; Jasiuk, I.; Sobh, N.A. Acoustic band gaps and elastic stiffness of PMMA cellular solids based on triply periodic minimal surfaces. Mater. Des. 2018, 145, 20-27. [CrossRef] 
268. Delpero, T.; Schoenwald, S.; Zemp, A.; Bergamini, A. Structural engineering of three-dimensional phononic crystals. J. Sound Vib. 2016, 363, 156-165. [CrossRef]

269. Lu, Y.; Yang, Y.; Guest, J.K.; Srivastava, A. 3-D phononic crystals with ultra-wide band gaps. Sci. Rep. 2017, 7, 43407. [CrossRef]

270. D'Alessandro, L.; Zega, V.; Ardito, R.; Corigliano, A. 3D auxetic single material periodic structure with ultra-wide tunable bandgap. Sci. Rep. 2018, 8, 1-9. [CrossRef] [PubMed]

271. Kennedy, J.; Flanagan, L.; Dowling, L.; Bennett, G.; Rice, H.; Trimble, D. The influence of additive manufacturing processes on the performance of a periodic acoustic metamaterial. Int. J. Polym. Sci. 2019, 2019, 7029143. [CrossRef]

272. Ivanova, O.; Elliott, A.; Campbell, T.; Williams, C. Unclonable security features for additive manufacturing. Addit. Manuf. 2014, 1, 24-31. [CrossRef]

Publisher's Note: MDPI stays neutral with regard to jurisdictional claims in published maps and institutional affiliations.

(C) 2020 by the authors. Licensee MDPI, Basel, Switzerland. This article is an open access article distributed under the terms and conditions of the Creative Commons Attribution (CC BY) license (http://creativecommons.org/licenses/by/4.0/). 